\title{
Hygroscopic properties of $\mathrm{NaCl}$ and $\mathrm{NaNO}_{3}$ mixture particles as reacted inorganic sea-salt aerosol surrogates
}

\author{
D. Gupta, H. Kim, G. Park, X. Li, H.-J. Eom, and C.-U. Ro \\ Department of Chemistry, Inha University, Incheon, 402-751, South Korea \\ Correspondence to: C.-U. Ro (curo@inha.ac.kr)
}

Received: 24 November 2014 - Published in Atmos. Chem. Phys. Discuss.: 23 December 2014

Revised: 21 February 2015 - Accepted: 3 March 2015 - Published: 26 March 2015

\begin{abstract}
NaCl}$ in fresh sea-salt aerosol (SSA) particles can partially or fully react with atmospheric $\mathrm{NO}_{\mathrm{x}} / \mathrm{HNO}_{3}$, so internally mixed $\mathrm{NaCl}$ and $\mathrm{NaNO}_{3}$ aerosol particles can co-exist over a wide range of mixing ratios. Laboratorygenerated, micrometer-sized $\mathrm{NaCl}$ and $\mathrm{NaNO}_{3}$ mixture particles at 10 mixing ratios (mole fractions of $\mathrm{NaCl}\left(X_{\mathrm{NaCl}}\right)=$ 0.1 to 0.9 ) were examined systematically to observe their hygroscopic behavior, derive experimental phase diagrams for deliquescence and efflorescence, and understand the efflorescence mechanism. During the humidifying process, aerosol particles with the eutonic composition $\left(X_{\mathrm{NaCl}}=\right.$ 0.38) showed only one phase transition at their mutual deliquescence relative humidity (MDRH) of $67.9( \pm 0.5) \%$. On the other hand, particles with other mixing ratios showed two distinct deliquescence transitions; i.e., the eutonic component dissolved at MDRH, and the remainder in the solid phase dissolved completely at their DRHs depending on the mixing ratios, resulting in a phase diagram composed of four different phases, as predicted thermodynamically. During the dehydration process, $\mathrm{NaCl}$-rich particles $\left(X_{\mathrm{NaCl}}\right.$ $>0.38$ ) showed a two stage efflorescence transition: the first stage was purely driven by the homogeneous nucleation of $\mathrm{NaCl}$ and the second stage at the mutual efflorescence $\mathrm{RH}$ (MERH) of the eutonic components, with values in the range of 30.0-35.5\%. Interestingly, aerosol particles with the eutonic composition $\left(X_{\mathrm{NaCl}}=0.38\right)$ also showed two-stage efflorescence, with $\mathrm{NaCl}$ crystallizing first followed by heterogeneous nucleation of the remaining $\mathrm{NaNO}_{3}$ on the $\mathrm{NaCl}$ seeds. $\mathrm{NaNO}_{3}$-rich particles $\left(X_{\mathrm{NaCl}} \leq 0.3\right)$ underwent singlestage efflorescence transitions at ERHs progressively lower than the MERH because of the homogeneous nucleation of $\mathrm{NaCl}$ and the almost simultaneous heterogeneous nucleation of $\mathrm{NaNO}_{3}$ on the $\mathrm{NaCl}$ seeds. SEM/EDX elemental map-
\end{abstract}

ping indicated that the effloresced $\mathrm{NaCl}-\mathrm{NaNO}_{3}$ particles at all mixing ratios were composed of a homogeneously crystallized $\mathrm{NaCl}$ moiety in the center, surrounded either by the eutonic component (for $X_{\mathrm{NaCl}}>0.38$ ) or $\mathrm{NaNO}_{3}$ (for $X_{\mathrm{NaCl}} \leq 0.38$ ). During the humidifying or dehydration process, the amount of eutonic composed part drives particle/droplet growth or shrinkage at the MDRH or MERH (second ERH), respectively, and the amount of pure salts $\left(\mathrm{NaCl}\right.$ or $\mathrm{NaNO}_{3}$ in NaCl- or $\mathrm{NaNO}_{3}$-rich particles, respectively) drives the second DRHs or first ERHs, respectively. Therefore, their behavior can be a precursor to the optical properties and direct radiative forcing for these atmospherically relevant mixture particles representing the coarse, reacted inorganic SSAs. In addition, the $\mathrm{NaCl}-\mathrm{NaNO}_{3}$ mixture aerosol particles can maintain an aqueous phase over a wider $\mathrm{RH}$ range than pure $\mathrm{NaCl}$ particles as SSA surrogate, making their heterogeneous chemistry more probable.

\section{Introduction}

Atmospheric aerosols play important roles in global climate change, directly by scattering or absorbing incoming solar radiation and indirectly by serving as cloud condensation nuclei (Pandis et al., 1995; Satheesh and Moorthy, 2005). The radiative effects depend on the chemical composition and sizes of the atmospheric aerosol particles. The optical properties and the chemical reactivity of the atmospheric aerosols also depend on their mixing states and different aerosol phases (Martin, 2000). Studies of the hygroscopic properties of inorganic salt particles as aerosol surrogates can provide better insights to several of these important aerosol properties, such as (1) alteration of aerodynamic properties; 
(2) cloud-droplet nucleation efficiency; (3) optical properties; and (4) physicochemical changes, through complex heterogeneous chemical reactions with atmospheric gas-phase species (Wang and Martin, 2007; Haywood and Boucher, 2000; ten Brink, 1998; Krueger et al., 2003).

Sea-salt or sea-spray aerosols (SSAs) comprise a large proportion of the atmospheric particulate mass (25-50\%) (Finlayson-Pitts and Pitts, 2000). Thus far, many studies have examined the hygroscopic behavior of both airborne and laboratory-generated SSAs (Tang et al., 1997; Wise et al., 2007, 2009; Prather et al., 2013), but the hygroscopicity of the SSAs is not completely understood (Meskhidze et al., 2013). $\mathrm{NaCl}$ in the nascent SSAs can react quickly (within a few minutes to an hour of residence in air) with the atmospheric $\mathrm{NO}_{\mathrm{x}} / \mathrm{HNO}_{3}$ (ten Brink, 1998; Saul et al., 2006; Liu et al., 2007). This can lead to the formation of partially or fully reacted particles containing $\mathrm{NaCl}$ and $\mathrm{NaNO}_{3}$ over a range of mixing ratios. Indeed, studies of individual marine aerosols have clearly shown the existence of fully or partially reacted SSA particles, and a significant portion of these particles were reported to be mixtures of sodium chloride, nitrate, and/or sulfate (Gard et al., 1998; Ro et al., 2001; Laskin et al., 2003; Ault et al., 2014). Moreover, the further reactive uptake of $\mathrm{N}_{2} \mathrm{O}_{5}$ was reported to be dependent on the chloride to nitrate ratio of the reacted SSAs and their phases (Ryder et al., 2014). The primary and secondary organics, biogenic particulates, sea-salt sulfates ( $\mathrm{ss}^{-\mathrm{SO}_{4}^{2-}}$ ), non-sea-salt sulfates (nss$\mathrm{SO}_{4}^{2-}$ ), etc., add greater complexity to these SSAs (O'Dowd and de Leeuw, 2007; Keene et al., 2007; Prather et al., 2013; Beardsley et al., 2013; Ault et al., 2013b). A detailed knowledge of the hygroscopic properties, mixing states, and the spatial distribution of the chemical components in $\mathrm{NaCl}-$ $\mathrm{NaNO}_{3}$ mixture particles, as partially or fully reacted SSA surrogates, can serve as a good preliminary step to a better understanding of the complex chemical/physical mixing states, hygroscopic behavior, and reactivity of ambient SSAs.

Many studies have examined the hygroscopic properties of two-component inorganic salt particles as inorganic aerosol surrogates (Cohen et al., 1987a; Tang and Munkelwitz, 1993, 1994a, b; Tang et al., 1978; Ge et al., 1996, 1998; Chang and Lee, 2002). Stepwise phase transitions generally occur for particles composed of two inorganic salts during the humidifying process (Wexler and Seinfeld, 1991). On the other hand, particles with the eutonic composition deliquesce completely at the mutual deliquescence relative humidity (MDRH), resulting in a single phase transition. For two-component inorganic hygroscopic salt particles, the first transition generally occurs at their MDRH, and the aqueous phase resulting from the partial deliquescence has the eutonic composition. The partially dissolved particles keep absorbing water with further increases in the $\mathrm{RH}$ and the residual solid component completely dissolves when the RH reaches their DRH, which depends on the composition of the particle. As the humidifying processes of in- organic salts are governed by thermodynamics, a range of thermodynamic models have been developed to predict the deliquescence behavior or the ionic activity coefficients of two-component aerosol particles (Tang, 1976; Ansari and Pandis, 1999; Clegg et al., 1998; Wexler and Clegg, 2002; Zuend et al., 2008, 2011). The Extended Atmospheric Inorganics Model (E-AIM) predicts the physical state and chemical compositions of aerosols containing several atmospherically relevant inorganic ionic species and/or organic species (http://www.aim.env.uea.ac.uk/aim/aim.php). The Aerosol Inorganic-Organic Mixtures Functional groups Activity Coefficient (AIOMFAC) model allows calculations of the activity coefficients in organic and/or inorganic mixtures from simple binary solutions to complex multicomponent systems (http://www.aiomfac.caltech.edu). On the other hand, there have been few systematic, experimental hygroscopic studies to support the theoretical models for mixed salt particles.

During the dehydration process, where the RH is decreased from high to low, the concentration of single salts in the aqueous droplets becomes dense and the inorganic single salts can be finally crystallized at their efflorescence RH (ERH). The ERH is sometimes significantly lower than the DRH. For example, pure $\mathrm{NaCl}$ particles have a DRH of $\sim 75$ and ERH of $\sim 45-47 \%$ (Martin, 2000). From a thermodynamic point of view, or as observed in bulk ternary systems, aqueous droplets with double salts should show step-wise efflorescence transitions: a component in the aqueous droplets precipitates first at their ERH and then the aqueous phase of the eutonic composition effloresces at their mutual ERH (MERH), which should be lower than either ERHs of the pure salts. Therefore, effloresced mixed particles may form a heterogeneous, core-shell crystal structure owing to the stepwise crystallization process (Ge et al., 1996). On the other hand, aqueous droplets with a eutonic composition are expected to crystallize simultaneously, resulting in a homogeneous crystal structure. Efflorescence, however, is a kinetic or rate-driven process that requires a sufficient activation energy to overcome the kinetic barrier (Martin, 2000). This kinetic or critical-nucleation barrier in turn depends on a range of factors, such as the mixing states of the chemical components, micro-physical states, supersaturation levels, vapor pressure, interfacial tension, viscosity, inter-ionic forces, and solute-water and solute-solute interactions (Cohen et al., 1987b). Therefore, the ERHs of single or multi-component salts are difficult to predict theoretically (Seinfeld and Pandis, 2006). A theoretical model for the efflorescence behavior of the $\mathrm{NaCl}-\mathrm{Na}_{2} \mathrm{SO}_{4}$ mixed system was reported, where the efflorescence was considered to be driven primarily by the homogeneous nucleation of the more supersaturated salt, resulting in a sufficiently large seed for the subsequent heterogeneous nucleation of the other salt (Gao et al., 2007). However, there is no general model that covers the efflorescence of multi-component particles, because it depends on many complicated parameters and varies with the salt characteris- 
tics. Therefore, the best way to understand the efflorescence behavior of aerosols is through experimental measurements (Seinfeld and Pandis, 2006). For example, a recent experimental study of the two component $\mathrm{NaCl}-\mathrm{KCl}$ mixture particles showed that during the dehydration process, the aqueous droplets of various mixing ratios underwent single step efflorescence ( $\mathrm{Li}$ et al., 2014). Based on the experimentally obtained efflorescence phase diagram and X-ray elemental maps of the effloresced $\mathrm{NaCl}-\mathrm{KCl}$ mixture particles at various mixing ratios, it was suggested that the more supersaturated salt nucleated homogeneously to crystallize in the center and the other salt underwent heterogeneous crystallization on the former almost simultaneously in the time-scale of the measurements. Full phase diagrams, covering the entire range of mixing ratios, are needed to fully understand the hygroscopic behavior of multi-component aerosol particles (Martin, 2000).

Up until now, there have been only a few studies on the hygroscopic properties of mixed $\mathrm{NaCl}-\mathrm{NaNO}_{3}$ aerosol system. Tang and Munkelwitz (1994a) examined the temperature dependent deliquescence behavior of equimolar mixed $\mathrm{NaCl}-$ $\mathrm{NaNO}_{3}$ particles using a single-particle levitation technique. Ge et al. (1998) also studied the deliquescence behavior of mixed $\mathrm{NaCl}-\mathrm{NaNO}_{3}$ particles with a $\mathrm{NaCl}$ mole fraction of $0.2,0.378$ (eutonic), and 0.8 using rapid single-particle mass spectrometry (RSMS), where only MDRH was measured experimentally, and it was claimed that the secondstage DRHs agreed with the thermodynamic predictions of AIM. Although the crystallization process was not studied experimentally, a core-shell type of heterogeneous morphology in the $\mathrm{NaCl}-\mathrm{NaNO}_{3}$ particles was proposed based on the two-step deliquescence phase transitions observed during the humidifying process (Ge at al., 1998; Hoffmann et al, 2004) and by measuring the secondary electron yields from the nebulized mixture particles (Ziemann and McMurry, 1997). On the other hand, as observed for the $\mathrm{NaCl}-$ $\mathrm{KCl}$ mixture particles, particles that exhibit two-step deliquescence phase transitions do not always have a core-shell type (Li et al., 2014). Moreover, it was reported that pure $\mathrm{NaNO}_{3}$ droplets do not crystallize easily during the dehydration process, and at very low RHs they appear to exist in an amorphous form (Hoffmann et al, 2004; Gibson et al., 2006; $\mathrm{Kim}$ et al., 2012). Therefore, the mixing states in $\mathrm{NaCl}-$ $\mathrm{NaNO}_{3}$ particles can be understood only when the efflorescence phenomena for these mixture particles are elucidated. In this study, the hygroscopic properties and microstructure of mixed $\mathrm{NaCl}-\mathrm{NaNO}_{3}$ particles at various mixing ratios were examined extensively by optical microscopy and scanning electron microscopy/energy dispersive X-ray spectroscopy (SEM/EDX). The phase transitions of the mixed $\mathrm{NaCl}-\mathrm{NaNO}_{3}$ aerosol particles were observed by monitoring the size changes of the particles on the optical images as a function of the RH. SEM/EDX mapping was used to investigate the compositional distribution in the effloresced particles. This paper describes the hygroscopic behavior of the
$\mathrm{NaCl}-\mathrm{NaNO}_{3}$ binary aerosol particles as reacted SSA surrogates at 10 different mixing ratios for the first time.

\section{Experimental section}

\subsection{Preparation of mixed $\mathrm{NaCl}-\mathrm{NaNO}_{3}$ particles}

Mixed $\mathrm{NaCl}-\mathrm{NaNO}_{3}$ particles were generated by the nebulization of mixed aqueous solutions. Pure solutions (1.0 M) of $\mathrm{NaCl}$ and $\mathrm{NaNO}_{3}(\mathrm{NaCl},>99.9 \%$ purity, Aldrich; $\mathrm{NaNO}_{3}, 99.9 \%$ purity, Aldrich) were prepared, and the desired solution was made by mixing the two solutions volumetrically. A single jet atomizer (HCT4810) was used to generate aerosol particles to be deposited on transmission electron microscopy (TEM) grids (200 mesh $\mathrm{Cu}$ coated with Formvar stabilized with carbon, Ted Pella, Inc.), which behave as hydrophobic substrates (Eom et al., 2014). The aqueous aerosol particles were dried by passing through a silica packed diffusion dryer (HCT4920) with a residence time of $\sim 2 \mathrm{~s}$. The size of the dry particles ranged from 1 to $10 \mu \mathrm{m}$.

In this study, $\mathrm{NaCl}-\mathrm{NaNO}_{3}$ particles with 10 different mixing ratios were investigated; i.e., 9 compositions with $\mathrm{NaCl}$ mole fractions of $0.1-0.9\left(X_{\mathrm{NaCl}}=0.1,0.2,0.3,0.4\right.$, $0.5,0.6,0.7,0.8$, and 0.9 , where $X_{\mathrm{NaCl}}$ represents the mole fraction of $\mathrm{NaCl}$. $)$ and a eutonic composition $\left(X_{\mathrm{NaCl}}=0.38\right.$, which was calculated from the ionic activity products predicted by the AIOMFAC model). Based on the mixing ratio of two salts, the mixed $\mathrm{NaCl}-\mathrm{NaNO}_{3}$ particles were divided into three categories: (1) eutonic particles $\left(X_{\mathrm{NaCl}}=0.38\right)$, (2) $\mathrm{NaCl}$-rich particles containing larger $\mathrm{NaCl}$ fraction than the eutonic composition $\left(X_{\mathrm{NaCl}}>0.38\right)$, and (3) $\mathrm{NaNO}_{3}$-rich particles containing larger $\mathrm{NaNO}_{3}$ fraction than the eutonic composition $\left(X_{\mathrm{NaCl}}<0.38\right)$.

\subsection{Hygroscopic property measurement}

The hygroscopic properties of the particles were investigated using a "see-through" inertia impactor apparatus equipped with an optical microscope. The experimental set-up is described in detail elsewhere (Ahn et al., 2010). Briefly, the apparatus is composed of three parts: (a) see-through impactor, (b) optical microscope and (c) humidity controlling system. A TEM grid on which aerosol particles were deposited was mounted on the impaction plate in the see-through impactor. The RH inside the impactor was controlled by mixing dry and wet (saturated with water vapor) $\mathrm{N}_{2}$ gases. The wet $\mathrm{N}_{2}$ gas was obtained by bubbling through deionized water reservoirs. The flow rates of the dry and wet $\mathrm{N}_{2}$ gases were controlled by mass flow controllers to obtain the desired RH in the range of 3-93\%, which was monitored using a digital hygrometer (Testo 645). The digital hygrometer was calibrated using a dew-point hygrometer (M2 Plus-RH, $\mathrm{GE}$ ), providing $\mathrm{RH}$ readings with $\pm 0.5 \%$ reproducibility. To achieve a steady state for condensing or evaporating water, each humidity condition was sustained for at least $2 \mathrm{~min}$. The 
particles on the impaction plate were observed through a nozzle throat using an optical microscope (Olympus, BX51M). Images of the particles were recorded continuously using a digital camera (Canon EOS 5D, full frame, Canon EF f/3.5 L macro USM lens) during the humidifying (by increasing $\mathrm{RH}$ from $\sim 3$ to $\sim 93 \%$ ) and dehydration (by decreasing $\mathrm{RH}$ from $\sim 93$ to $\sim 3 \%$ ) experiments. The image size was $4368 \times 2912$ pixels, and the image recording condition was set to ISO200. The exposure time was $0.4 \mathrm{~s}$, and the depth of focus (DOF) was F/3.5. All hygroscopic experiments were conducted at room temperature $\left(T=22 \pm 1{ }^{\circ} \mathrm{C}\right)$.

The change in particle size with the variation of $\mathrm{RH}$ was monitored by measuring the particle areas in the optical images. The particle images were processed using image analysis software (Matrox, Inspector v9.0). The size of the imaging pixel was calibrated using $10 \mu \mathrm{m}$ Olympus scale bars. Particles with $D_{\mathrm{p}}>0.5 \mu \mathrm{m}$ could be analyzed using the present system (Ahn et al., 2010; Eom et al., 2014).

\subsection{SEM/EDX measurement}

After the hygroscopicity measurements of the individual particles, SEM/EDX was performed for the effloresced particles to determine the morphology and spatial distribution of the chemical elements (Ahn et al., 2010; Li et al., 2014). The measurements were carried out using a Jeol JSM-6390 SEM equipped with an Oxford Link SATW ultrathin window EDX detector. The resolution of the detector was $133 \mathrm{eV}$ for the $\mathrm{Mn} \mathrm{K} \alpha \mathrm{X}$-rays. The X-ray spectra and elemental maps were recorded under the control of Oxford INCA Energy software. A $10 \mathrm{kV}$ accelerating voltage and $0.2 \mathrm{nA}$ beam current was used and the typical measuring times were $10 \mathrm{~min}$ for elemental mapping.

\section{Results and discussion}

\subsection{Hygroscopic behavior of pure $\mathrm{NaCl}$ and $\mathrm{NaNO}_{3}$ particles}

Aerosol particles generated from a pure $\mathrm{NaCl}$ aqueous solution showed typical hysteresis curves with DRH $=75.5$ $( \pm 0.5) \%$ and $\mathrm{ERH}=47.6-46.3 \%$, and these values were consistent with the reported values (Wise et al., 2007; Tang et al., 1997). The DRH and ERH of the single-component $\mathrm{NaCl}$ aerosol particles are denoted as those of the "pure $\mathrm{NaCl}$ limit". The dry-deposited $\mathrm{NaNO}_{3}$ powder particles exhibited typical hygroscopic curves with definite phase transitions at $\mathrm{DRH}=74.0( \pm 0.5) \%$, and $\mathrm{ERH}=45.7-26.7 \%$, which are similar to the values reported by Tang and Munkelwitz (1994b). Hereafter, the DRH of the "pure $\mathrm{NaNO}_{3}$ limit" is defined as $74.0 \%$. On the other hand, most wet deposited aerosol particles (>90\%) generated by nebulization from a $\mathrm{NaNO}_{3}$ aqueous solution grew continuously and shrank without any phase transition during the humidifying and dehydration processes, which have also been reported (Gysel et al., 2002; McInnes et al., 1996; Lee et al., 2000; Hoffman et al., 2004). However, a few wet deposited particles showed ERH in the range, 25.8-18.9\%. This discrepancy was attributed to the different nucleation mechanisms, i.e. homogeneous and heterogeneous nucleation, for pure and impure (seed containing) $\mathrm{NaNO}_{3}$ particles, respectively. Detailed discussions can be found elsewhere (Kim et al., 2012). Nebulized $\mathrm{NaNO}_{3}$ particles may exist as amorphous particles with no visible ERHs (Hoffmann et al., 2004; Kim et al., 2012).

\subsection{Hygroscopic behavior of mixed $\mathrm{NaCl}-\mathrm{NaNO}_{3}$ particles}

To describe the measurement procedure for observing the hygroscopic behavior of individual aerosol particles during humidifying and dehydration processes, Fig. 1 presents representative optical images of $\mathrm{NaCl}-\mathrm{NaNO}_{3}$ particles with a NaCl-rich composition, i.e., $X_{\mathrm{NaCl}}=0.8$, taken at various RHs. Images $(\mathrm{a}-\mathrm{e})$ and $(\mathrm{f}-\mathrm{j})$ were recorded when the RH was first increased ( $\uparrow$ ) from $\sim 3$ to $90 \%$ (humidifying process), and then decreased $(\downarrow)$ from $\sim 90$ to $3 \%$ (dehydration process), respectively. As the optical images of the particles were recorded using a digital camera, the data for 10-15 particles in each image field was obtained. During the humidifying process, the sizes and shapes of the particles did not change until all the particles absorbed moisture and showed a first partial deliquescence transition at $\mathrm{RH}=67.9( \pm 0.5) \%$, which is the DRH of the eutonic composed part (i.e., $X_{\mathrm{NaCl}}=0.38$ ) (see Fig. 2c). Upon further increases in $\mathrm{RH}$, the particles absorbed more moisture and grew in size until a second deliquescence transition occurred at $\mathrm{RH}=73.7 \%$, where all the particles were fully converted to homogeneous aqueous droplets. After the second deliquescence transition, liquid droplets underwent hygroscopic growth with increasing RH due to the condensation of water vapor. During the dehydration process, the aqueous droplets decreased gradually in size, until the first efflorescence transitions were observed over the range of $\mathrm{RH}=45.2-44.7 \%$ for different droplets in the image field, where they became partially crystallized. Upon further decreases in RH, they underwent a second and final efflorescence transition over the range of $\mathrm{RH}=33.5-30.0 \%$. All particles in the image field were finally transformed into solids at $\mathrm{RH}=30.0 \%$, below which no further decrease in size was observed. All the particles in the image field showed two-stage deliquescence transitions at specific RHs because the deliquescence transitions are prompt. On the other hand, the two-stage efflorescence transitions occurred over a range of RH because the efflorescence driven by the nucleation kinetics is a stochastic process (Martin, 2000; Krieger et al., 2012). As the projected optical image of a particle placed on the substrate was monitored during the hygroscopic measurements, the shape and size of the effloresced particles did not appear the same as the orig- 


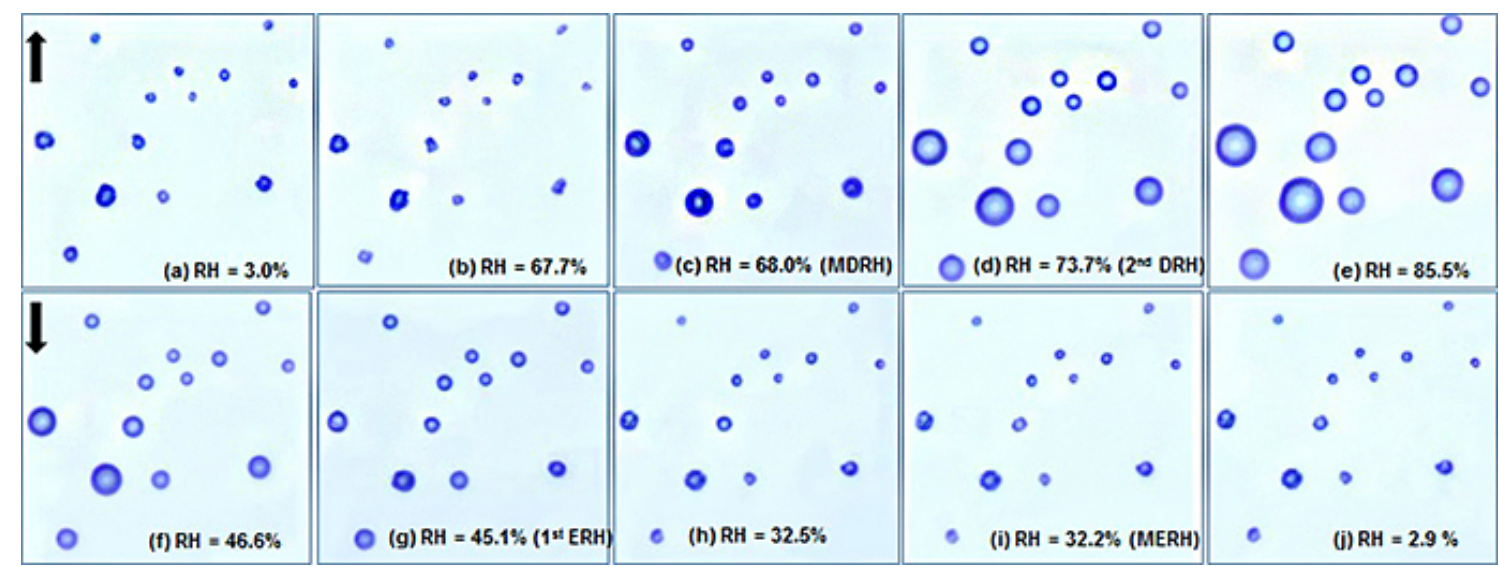

Figure 1. Optical images of $\mathrm{NaCl}-\mathrm{NaNO}_{3}$ particles with a mole fraction of $X_{\mathrm{NaCl}}=0.8$, obtained during humidifying ( $\uparrow$ ) and dehydration $(\downarrow)$ processes for the same image field.

inal dry particle due to the rearrangement of a solid particle when it crystallizes during the dehydration process.

Figure 2 presents the humidifying and dehydration curves for mixed $\mathrm{NaCl}-\mathrm{NaNO}_{3}$ particles at different mixing ratios. The humidifying and dehydration curves are represented as the area ratio $\left(A / A_{\mathrm{o}}\right.$ : left-hand axis), which was obtained by dividing the 2-D projected particle area at a given $\mathrm{RH}(A)$ by that before starting the humidifying process $\left(A_{\mathrm{o}}\right)$. The hygroscopic behavior of the mixed $\mathrm{NaCl}-\mathrm{NaNO}_{3}$ particles differed according to the categories, i.e. eutonic, $\mathrm{NaCl}$-rich, and $\mathrm{NaNO}_{3}$-rich particles, which are discussed in the next sections.

\subsubsection{Eutonic particles $\left(X_{\mathrm{NaCl}}=\mathbf{0 . 3 8}\right)$}

Figure 2c shows the 2-D projected area ratio plot as a function of the RH obtained during humidifying and dehydration processes for a representative eutonic particle. During the humidifying process, a single phase transition from solid particles to liquid droplets was observed at $\mathrm{RH}=67.1-67.9 \%$. After deliquescence, the size of the liquid droplet grew gradually and continuously with further increases in RH. As the eutonic particles deliquesced at $\mathrm{RH}=67.9( \pm 0.5) \%$, they approached the MDRH of the mixed $\mathrm{NaCl}-\mathrm{NaNO}_{3}$ particles. The measured MDRH is consistent with the value calculated from the ionic activity products predicted by the AIOMFAC model and other experimental values (Tang and Munkelwitz, 1994a). During the dehydration process, however, the eutonic droplets showed two-stage efflorescence transitions. The particle (Fig. 2c) decreased gradually in size due to water evaporation and the particle size decreased sharply at the first efflorescence transition at $\mathrm{RH}=37.3-36.6 \%$. The particle was then observed to undergo a second efflorescence transition at $\mathrm{RH}=35.3-34.4 \%$. All eutonic droplets in the optical image field showed first and second ERHs over the range of $\mathrm{RH}=37.7-35.7$ and $35.4-33.4 \%$, respectively.
In general, the effloresced particle areas are different from the original ones; i.e., the $A / A_{0}$ values deviate from unity (see Fig. 2) due to the rearrangement of the particles during recrystallization. Because only the top-view 2-D images are obtained from particles sitting on the substrate, the morphology of the particles may not appear the same after recrystallization unless they are perfectly spherical.

\subsubsection{NaCl-rich particles $\left(X_{\mathrm{NaCl}}>0.38\right)$}

Figure 2e presents the 2-D-area ratio plot as a function of the $\mathrm{RH}$ of a NaCl-rich particle $\left(X_{\mathrm{NaCl}}=0.8\right)$. During the humidifying process, the particle size remained constant until $\mathrm{RH}=\sim 65.5 \%$, where a slight decrease in size was observed due to water adsorption in the lattice imperfections of the solid salts in the particle and structural rearrangement inside the crystal lattice. A first deliquescence transition was observed from $\mathrm{RH}=67.7$ to $68.0 \%$, where its size increased sharply. With further increases in $\mathrm{RH}$, it grew gradually until $\mathrm{RH}=73.7 \%$, at which point the second transition occurred. Thereafter, with further increases in $\mathrm{RH}$, the particle grew continuously. The first phase transition at $\mathrm{RH}=68.0 \%$, i.e., MDRH $(\mathrm{RH}=67.9( \pm 0.5) \%)$ of the $\mathrm{NaCl}-\mathrm{NaNO}_{3}$ system, was assigned to the deliquescence of the eutonic component in the particle. At the MDRH, the particle consisted of a mixed phase of liquid droplets (eutonic solution) and $\mathrm{NaCl}$ solid inclusion. The solid inclusions in the partially deliquesced mixed inorganic salt particles were also observed by environmental transmission electron microscopy (ETEM) (Freney et al., 2009, 2010). Above the MDRH, with the increase in $\mathrm{RH}$, water vapor kept being absorbed, and $\mathrm{NaCl}$ solid dissolved thoroughly at $\mathrm{RH}=73.7 \%$, which is the second DRH of the particles with $X_{\mathrm{NaCl}}=0.8$.

All other NaCl-rich particles with different compositions (e.g., $X_{\mathrm{NaCl}}=0.5$ and 0.9 in Fig. $2 \mathrm{~d}$ and f, respectively) also exhibited two-stage phase transitions during the humidifying process: the first transition at MDRH $(\mathrm{RH}=67.9( \pm 0.5) \%)$ 

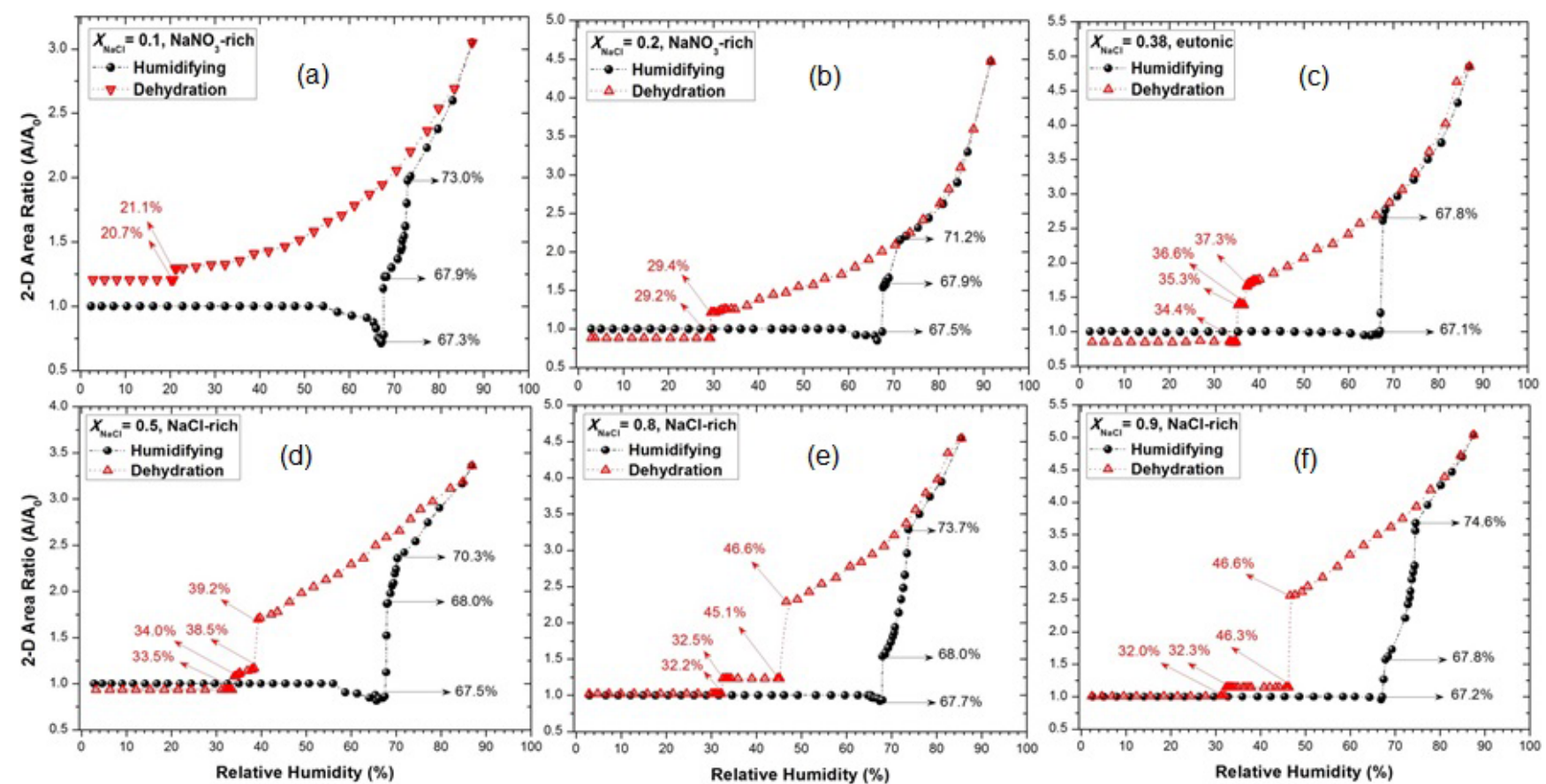

Figure 2. Plots of 2-D projected area ratio as a function of the relative humidity (humidifying process: closed circles; dehydration process: open triangles) for different mole fractions of $\mathrm{NaCl}-\mathrm{NaNO}_{3}$, expressed in $X_{\mathrm{NaCl}}$ values of (a) 0.1 ( $\mathrm{NaNO}_{3}$-rich), (b) 0.2 (NaNO 3 -rich), (c) 0.38 (eutonic), (d) 0.5 (equimolar/NaCl-rich), (e) 0.8 (NaCl-rich), and (f) 0.9 (NaCl-rich). The transition relative humidity in both humidifying and dehydration processes are marked with arrows.

due to deliquescence of the eutonic component and the second one at their DRHs owing to complete deliquescence of the particles. The MDRH is independent of the particle composition. On the other hand, the second DRHs are dependent on the compositions and shift toward the pure $\mathrm{NaCl}$ limit $(\mathrm{DRH}=75.5( \pm 0.5) \%$ ) with increasing $\mathrm{NaCl}$ mole fraction. Figure 3 plots the measured DRHs for the NaCl-rich particles with various compositions as a function of the $\mathrm{NaCl}$ mole fraction, showing that the experimental DRH values are in good agreement with the values calculated from the AIOMFAC model.

During the dehydration process (Fig. 2e), a representative NaCl-rich particle with the composition of $X_{\mathrm{NaCl}}=0.8$ shows two-stage phase transition. The liquid droplet gradually decreased in size with decreasing RH and became supersaturated by $\mathrm{NaCl}$ below $73.7 \% \mathrm{RH}$ (DRH for $X_{\mathrm{NaCl}}$ $=0.8$ ). With the further decreases in RH, the droplet size decreased sharply at $\mathrm{RH}=46.6-45.1 \%$ due to the crystallization of $\mathrm{NaCl}$ in the droplet. At $\mathrm{RH}=45.1 \%$, the first ERH for $X_{\mathrm{NaCl}}=0.8$, the particle was composed of a mixed phase of eutonic solution and $\mathrm{NaCl}$ solid. With further decreases in $\mathrm{RH}$, the eutonic component in the particle precipitated at $\mathrm{RH}=32.2 \%$, which is the MERH of the aerosol particle, resulting in the formation of a completely effloresced solid particle. The measured first ERH and MERH for the particles with a composition of $X_{\mathrm{NaCl}}=0.8$ varied among the particles and were in the range, $\mathrm{RH}=45.2-44.7 \%$ and
$\mathrm{RH}=33.5-30.0 \%$, respectively. All other NaCl-rich particles with different compositions also exhibited two-stage transitions during the dehydration process: the first transition at their ERH, which is specific to their compositions, owing to the homogeneous nucleation and crystallization of $\mathrm{NaCl}$, and the second transition at the MERH due to precipitation of the eutonic component.

As the NaCl-rich particles show two-stage phase transitions during the dehydration process, they may form a coreshell type structure where the crystalline $\mathrm{NaCl}$ occupies the center and the eutonic solid is present at the surface. Detailed microstructures of the effloresced $\mathrm{NaCl}$-rich particles will be discussed later.

\subsection{3 $\mathrm{NaNO}_{3}$-rich particles $\left(X_{\mathrm{NaCl}}<0.38\right)$}

All $\mathrm{NaNO}_{3}$-rich particles also showed two-stage transitions during the humidifying process. For example, in Fig. 2b, a $\mathrm{NaNO}_{3}$-rich particle with the composition of $X_{\mathrm{NaCl}}=0.2$ showed the first and second transition at $\mathrm{RH}=67.5-67.9 \%$ $(\mathrm{MDRH})$ and $\mathrm{RH}=71.2 \%$, respectively. At the MDRH, the deliquesced component formed a eutonic aqueous solution and the un-deliquesced $\mathrm{NaNO}_{3}$ solid was still included in the eutonic solution. Above MDRH, the aerosol particle absorbed water continuously with a further increase in the RH, and it deliquesced completely at $\mathrm{RH}=71.2 \%$, which is the second DRH of the particle of $X_{\mathrm{NaCl}}=0.2$. Above DRH, the 


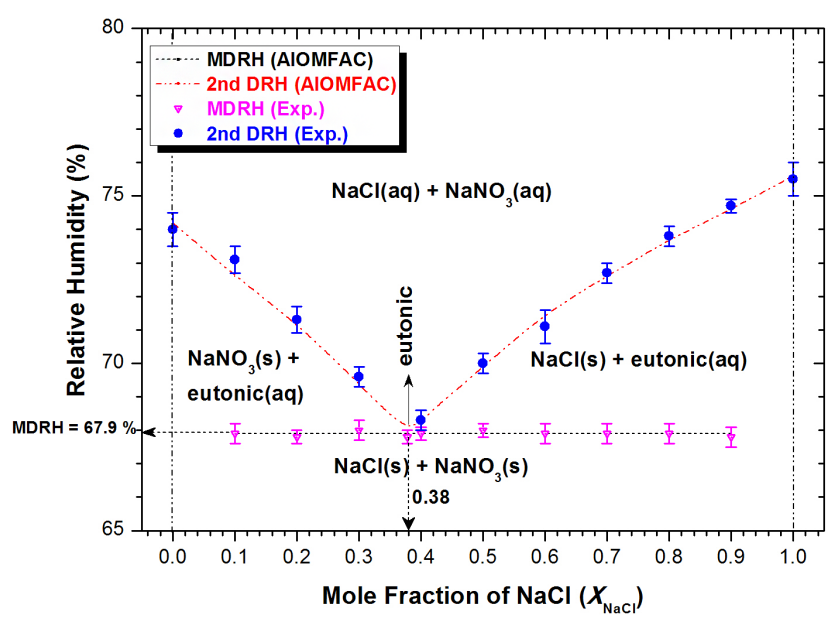

Figure 3. Measured first DRH or MDRH (open triangles), second DRH (closed circles) values, calculated MDRH (dotted line), and the second DRHs (dash-dotted curve) from the AIOMFAC, plotted as a function of the mole fraction of $\mathrm{NaCl}$ in $\mathrm{NaCl}-\mathrm{NaNO}_{3}$ mixture particles. The phase notations shown in brackets are $\mathrm{s}=$ solid; and $\mathrm{aq}=$ aqueous.

size of the liquid droplet increased with increasing RH due to the condensation of water vapor. Other $\mathrm{NaNO}_{3}$-rich particles (e.g., $X_{\mathrm{NaCl}}=0.1$ in Fig. 2a) also exhibited two-stage phase transitions during the humidifying process: the first transition at MDRH due to the deliquescence of the eutonic component (independent of chemical composition) and the second one at their DRH due to the complete deliquescence of the particles. In all $\mathrm{NaNO}_{3}$-rich particles, the second DRH was dependent on the mixing ratio of the particles and shifted toward the pure $\mathrm{NaNO}_{3}$ limit $\left(\mathrm{DRH}\right.$ of $\left.\mathrm{NaNO}_{3}=74.0( \pm 0.5) \%\right)$ with increasing $\mathrm{NaNO}_{3}$ mole fraction (Fig. 3).

The hygroscopic behavior of the $\mathrm{NaNO}_{3}$-rich particles during the dehydration process was different from that of $\mathrm{NaCl}$-rich particles. The NaCl-rich particles showed twostage transitions, whereas the $\mathrm{NaNO}_{3}$-rich particles showed a single-stage transition. For example, a droplet of $X_{\mathrm{NaCl}}=$ 0.2 decreased continuously in size with decreasing RH until it showed an efflorescence transition at RH $=29.4-29.2 \%$ (Fig. 2b). Similar to the $\mathrm{NaCl}$-rich case, the $\mathrm{NaNO}_{3}$-rich particles would be expected to exhibit two-stage transitions during the dehydration process, i.e., the first transition accompanying the precipitation of solid $\mathrm{NaNO}_{3}$, and the second one due to the efflorescence of the eutonic component. However, all the $\mathrm{NaNO}_{3}$-rich particles with $X_{\mathrm{NaCl}}=0.1,0.2$, and 0.3 showed single-stage efflorescence transitions during the dehydration process (Figs. 2a, b, and 4), suggesting that all the components in the $\mathrm{NaNO}_{3}$-rich particles crystallized (almost) simultaneously. The supersaturated $\mathrm{NaNO}_{3}$ in the droplets did not appear to crystallize until the $\mathrm{NaCl}$ crystallized and acted as heterogeneous nuclei for the almost simultaneous solidification of $\mathrm{NaNO}_{3}$. To confirm this assumption, particles with small fractions of $\mathrm{NaCl}$, such as particles with $X_{\mathrm{NaCl}}=0.01,0.03$, and 0.05, were investigated. The particles with $X_{\mathrm{NaCl}}=0.05$ showed two-stage and single-stage transitions during the humidifying and dehydration processes, respectively, which is similar to that observed for the $\mathrm{NaNO}_{3}$-rich particles with a composition of $X_{\mathrm{NaCl}} \geq 0.1$. On the other hand, the particles with $X_{\mathrm{NaCl}}=$ 0.01 and 0.03 underwent continuous hygroscopic growth and shrinkage without phase transitions during the humidifying and dehydration processes, respectively, which is similar to that of aerosol particles generated from an aqueous singlecomponent $\mathrm{NaNO}_{3}$ solution. Pure nebulized $\mathrm{NaNO}_{3}$ did not show clear efflorescence transitions apparently because of its amorphous nature (Hoffman et al., 2004; Gibson et al., 2006; Kim et al., 2012). Therefore, a sufficient quantity of heterogeneous nuclei $(\mathrm{NaCl}$ in this case) is needed to induce the crystallization of $\mathrm{NaNO}_{3}$. A similar observation was reported for the crystallization of $\mathrm{NH}_{4} \mathrm{NO}_{3}$ and $\mathrm{NH}_{4} \mathrm{HSO}_{4}$ aerosol particles (Schlenker and Martin, 2005). Both the pure onecomponent salts did not effloresce, even at $\mathrm{RH}=1 \%$, and their crystallization could be promoted with the addition of some fraction of inclusions that could serve as good heterogeneous nuclei.

\subsection{Deliquescence phase diagram of mixed $\mathrm{NaCl}-\mathrm{NaNO}_{3}$ particles}

Figure 3 presents the measured MDRHs (the first DRHs) and second DRHs of the $\mathrm{NaCl}-\mathrm{NaNO}_{3}$ mixture particles with different mole fractions along with the measured DRHs of the pure $\mathrm{NaCl}$ and $\mathrm{NaNO}_{3}$ particles. As shown in Fig. 3, a clearly demarked phase diagram depicting their deliquescence behavior was obtained experimentally as follows:

1. $\mathrm{NaCl}(\mathrm{s})+\mathrm{NaNO}_{3}$ (s) phase in Fig. 3: both $\mathrm{NaCl}$ and $\mathrm{NaNO}_{3}$ are mixed as solids below the MDRH at all mole fractions;

2. $\mathrm{NaCl}(\mathrm{s})+$ eutonic(aq) phase: a mixed phase of solid $\mathrm{NaCl}$ and aqueous eutonic components between the MDRH and second DRHs for $X_{\mathrm{NaCl}}>0.38$;

3. $\mathrm{NaNO}_{3}(\mathrm{~s})+$ eutonic(aq) phase: a mixed phase of solid $\mathrm{NaNO}_{3}$ and aqueous eutonic components between the MDRH and second DRHs for $X_{\mathrm{NaCl}}<0.38$; and

4. $\mathrm{NaCl}(\mathrm{aq})+\mathrm{NaNO}_{3}(\mathrm{aq})$ phase: both $\mathrm{NaCl}$ and $\mathrm{NaNO}_{3}$ are mixed in the aqueous phase above the second DRHs at all mole fractions.

This MDRH and second DRHs obtained experimentally agrees well with the values calculated from the ionic activity products of constituents predicted by the AIOMFAC model, as shown in Fig. 3 (dotted line for MDRH and dashdotted curve for the second DRHs). Although many theoretical models have been developed to predict the hygroscopic behavior of a mixed sodium chloride and nitrate system (Tang, 1976; Ansari and Pandis, 1999; Clegg et al., 1998; 
Wexler and Clegg, 2002), only a few experimental results have been reported. Tang and Munkelwitz (1994a) reported an MDRH $=68.0( \pm 0.4) \%$ at $25^{\circ} \mathrm{C}$. Ge et al. (1998) examined the deliquescence behavior of mixed $\mathrm{NaCl}-\mathrm{NaNO}_{3}$ particles with a $\mathrm{NaCl}$ mole fraction of $0.2,0.38$ (eutonic), and 0.8 , using RSMS. They claimed that the DRHs were generally consistent with the AIM thermodynamic model predictions. On the other hand, the measured DRH values were not reported except for the MDRH of $67.0 \%$, which was lower than the $67.9 \%$ obtained in the present study, because the RSMS appeared to detect only the start of the transition similar to the present system where mutual deliquescence for $X_{\mathrm{NaCl}}=0.38$ began at $67.1 \%$ (Fig. 2b), whereas the actual MDRH was at the end of the transition at $67.9 \%$ when the eutonic particle dissolved completely.

All the mixed $\mathrm{NaCl}-\mathrm{NaNO}_{3}$ particles showed the first phase transition at the MDRH regardless of the mixing ratio of the two salts. Thermodynamically, as the phase transition of mixed-salts is governed by the water activity at the eutonic point, the MDRH of the mixed-salt particles is independent of the initial composition of the mixture. Other inorganic mixed particles, such as $\mathrm{NaCl}-\mathrm{KCl}, \mathrm{Na}_{2} \mathrm{SO}_{4}-\mathrm{NaNO}_{3}$ and $\mathrm{NH}_{4} \mathrm{Cl}-\mathrm{NaCl}$ particles, also exhibited a mutual deliquescence transition at RHs, which were independent of the initial dry-salt compositions, and the phase diagram followed the typical pattern for these two-component inorganic salt + water ternary systems (Tang and Munkelwitz, 1994a; Li et al., 2014; Kelly et al., 2008). For the NaCl-rich particles of $X_{\mathrm{NaCl}}>0.38$, which contain more $\mathrm{NaCl}$ than the eutonic composition, the second DRH value approached the DRH of the pure $\mathrm{NaCl}$ salt as the $\mathrm{NaCl}$ concentration was increased. For the $\mathrm{NaNO}_{3}$-rich particles of $X_{\mathrm{NaCl}}<0.38$, the DRH approached that of pure $\mathrm{NaNO}_{3}$ as the $\mathrm{NaNO}_{3}$ mole fraction was increased (Fig. 3). This suggests that the second-stage deliquescence is purely driven by the solid salt remaining after the first deliquescence of the eutonic composition.

\subsection{Efflorescence phase diagram of mixed $\mathrm{NaCl}-\mathrm{NaNO}_{3}$ particles}

Figure 4 shows the measured ERHs and MERHs for the mixed $\mathrm{NaCl}-\mathrm{NaNO}_{3}$ particles with various mixing ratios as a function of the $\mathrm{NaCl}$ mole fraction. Unlike the deliquescence phase diagram, which showed four systematic phases, the efflorescence phase diagram is composed of three distinct phases:

1. $\mathrm{NaCl}(\mathrm{aq})+\mathrm{NaNO}_{3}$ (aq) phase: both $\mathrm{NaCl}$ and $\mathrm{NaNO}_{3}$ are mixed in the aqueous phase above the first ERHs at all mixing ratios;

2. $\mathrm{NaCl}(\mathrm{s})+$ eutonic(aq) phase: a mixed phase of solid $\mathrm{NaCl}$ and aqueous eutonic components between the first ERH and second ERH (MERH) for $X_{\mathrm{NaCl}} \geq 0.38$; and

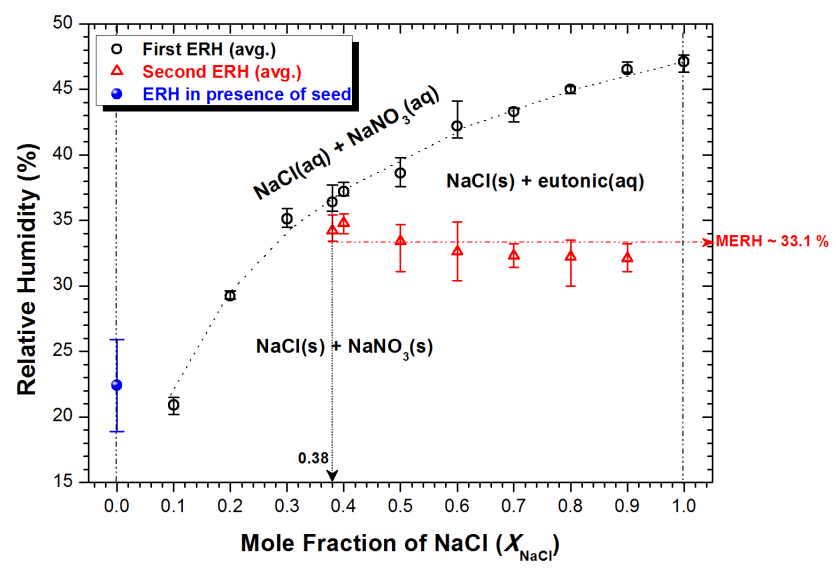

Figure 4. Measured first-ERH values (open circles) and secondERH values (open triangles) as a function of the mole fraction of $\mathrm{NaCl}$ in $\mathrm{NaCl}-\mathrm{NaNO}_{3}$ mixture particles as well as ERH (closed circle) for wet deposited $\mathrm{NaNO}_{3}$ particles containing seeds. The phase notations shown in brackets are $\mathrm{s}=$ solid; and $\mathrm{aq}=$ aqueous.

3. $\mathrm{NaCl}(\mathrm{s})+\mathrm{NaNO}_{3}(\mathrm{~s})$ phase: both $\mathrm{NaCl}$ and $\mathrm{NaNO}_{3}$ are mixed as solids below the second ERH (MERH) for $X_{\mathrm{NaCl}} \geq 0.38$ and below the first ERHs for $X_{\mathrm{NaCl}}$ $<0.38$.

This experimental phase diagram for efflorescence is reported for the first time, for which no theoretical predictions or other experimental reports exist to the best of the authors' knowledge.

The ERH of NaCl-rich droplets $\left(X_{\mathrm{NaCl}}>0.38\right)$ shifted toward the pure $\mathrm{NaCl}$ limit $(\mathrm{RH}=47.6-46.3 \%)$ when the $\mathrm{NaCl}$ content was increased (see Fig. 4). The measured MERH was observed at a relatively wide range of $\mathrm{RH}=30.0-35.5 \%$. The droplets with the eutonic composition $\left(X_{\mathrm{NaCl}}=0.38\right)$ showed the first and second ERHs over a range of 37.7-35.7 and $35.4-33.4 \%$, respectively. The $\mathrm{NaNO}_{3}$-rich droplets $\left(X_{\mathrm{NaCl}}<0.38\right)$ had only one-stage efflorescence transition, and the decreasing trend of their ERHs as the $\mathrm{NaCl}$ mole fraction was decreased clearly follows that for the $\mathrm{NaCl}$-rich and eutonic droplets (Fig. 4). This suggests that the first efflorescence of the $\mathrm{NaCl}-\mathrm{NaNO}_{3}$ mixture droplets at all mixing ratios is driven by the homogeneous nucleation of $\mathrm{NaCl}$. For the NaCl-rich droplets, crystallized $\mathrm{NaCl}$ acts as a seed for further precipitation of the remaining metastable eutonic aqueous part. For the eutonic droplets, $\mathrm{NaCl}$ is crystallized homogeneously at the first ERH and the remaining $\mathrm{NaNO}_{3}$ solidify heterogeneously on the $\mathrm{NaCl}$ seeds at the second ERH. For $\mathrm{NaNO}_{3}$-rich droplets, due to the low $\mathrm{NaCl}$ content, the homogeneous nucleation rate of $\mathrm{NaCl}$ decreases with decreasing $\mathrm{NaCl}$ mole fraction, and the $\mathrm{NaNO}_{3}$ appears to undergo almost simultaneous heterogeneous crystallization (precipitation) on the $\mathrm{NaCl}$ seeds under the time scale of measurements (i.e., within 2 min of the equilibrating time 
for recording images during the first observed efflorescence transition).

\subsection{Spatial distribution of effloresced $\mathrm{NaCl}-\mathrm{NaNO}_{3}$ solid particles}

To examine the morphology and spatial distribution of the chemical components in $\mathrm{NaCl}-\mathrm{NaNO}_{3}$ particles at various mixing ratios, SEM/EDX were performed for the effloresced solid particles formed after the humidifying and dehydration cycles. Figure 5a shows the secondary electron image (SEI) and elemental X-ray mapping images of a $\mathrm{NaCl}$ rich $\left(X_{\mathrm{NaCl}}=0.8\right)$ particle. The elemental X-ray maps suggest that $\mathrm{Cl}$ (from $\mathrm{NaCl}$ ) is concentrated in the central part, whereas $\mathrm{O}$ (from $\mathrm{NaNO}_{3}$ ) is more concentrated at the edges. This suggests that $\mathrm{NaCl}$ nucleates homogeneously to crystallize in the center at the first ERH, whereas $\mathrm{NaCl}$ and $\mathrm{NaNO}_{3}$ from the eutonic phase crystallized on these central $\mathrm{NaCl}$ seeds and precipitated on the edges at the second ERH (MERH).

For a typical particle with a eutonic composition $\left(X_{\mathrm{NaCl}}=\right.$ $0.38)$, the elemental map of $\mathrm{Cl}$ suggests that $\mathrm{NaCl}$ is again more concentrated at the central part, like NaCl-rich particles, and $\mathrm{O}$ from $\mathrm{NaNO}_{3}$ is concentrated around this $\mathrm{NaCl}$ core (Fig. 5b), suggesting that $\mathrm{NaCl}$ is nucleated homogeneously to crystallize in the center at the first ERH, whereas the remaining $\mathrm{NaNO}_{3}$ precipitated at the second ERH. The thermodynamically expected, homogeneously mixed eutonic particles were not observed, and the spatial distribution was rather ruled by the two-stage efflorescence transitions.

In the case of $\mathrm{NaNO}_{3}$-rich particles, as shown in Fig. 5c, the $\mathrm{Cl}$ component was localized in the core region, and $\mathrm{Na}$ and $\mathrm{O}$ are distributed over the entire particle. This suggests that even for $\mathrm{NaNO}_{3}$-rich particles, $\mathrm{NaCl}$ is nucleated homogeneously to crystallize in the core at the single observed ERHs, whereas the $\mathrm{NaNO}_{3}$ precipitate simultaneously on this core within the time scale of the measurements. Although the $\mathrm{NaNO}_{3}$-rich droplet was supersaturated with $\mathrm{NaNO}_{3}$ with decreasing $\mathrm{RH}$ during the dehydration process, $\mathrm{NaNO}_{3}$ could not crystallize easily even at the MERH of the $\mathrm{NaCl}$-rich mixtures. Therefore, RHs lower than MERH (see Fig. 4 for the lower ERHs in the case of $X_{\mathrm{NaCl}} \leq 0.3$ than MERH) were necessary for the homogeneous crystallization of $\mathrm{NaCl}$ followed by the almost simultaneous, induced heterogeneous crystallization of $\mathrm{NaNO}_{3}$.

Up until now, the binary inorganic salt aerosols, except the eutonic composition, are generally believed to form a coreshell type heterogeneous solid of a pure salt core surrounded by the eutonic component. The formation of the core-shell type had been reported for a range of binary mixed aerosol particles, such as $\mathrm{NaCl}-\mathrm{KCl}, \mathrm{KCl}-\mathrm{KI},\left(\mathrm{NH}_{4}\right)_{2} \mathrm{SO}_{4}-\mathrm{NH}_{4} \mathrm{NO}_{3}$ system (Ge et al., 1996). Based on the secondary electron yield measurements of the $\mathrm{NaCl}-\mathrm{NaNO}_{3}$ mixture particles, it was claimed that individual particles exist in core-shell form with the richer salt $\left(\mathrm{NaCl}\right.$ in $\mathrm{NaCl}$-rich or $\mathrm{NaNO}_{3}$ in
$\mathrm{NaNO}_{3}$-rich), and the eutonic components occupy the core and shell, respectively (Ziemann and McMurry, 1997). However, the study was conducted on particles nebulized from aqueous solutions that had not gone through the proper dehydration process. Hoffmann et al. (2004) predicted a coreshell type structure based on their observations of $\mathrm{NaCl}$ inclusions in the partially deliquesced particles only. On the other hand, a previous report on $\mathrm{NaCl}-\mathrm{KCl}$ mixture particles showed that $\mathrm{NaCl}$ and $\mathrm{KCl}$ were crystallized as separate phases and not necessarily in the core-shell configuration (Li et al., 2014). In addition, a eutonic solid shell in the dry particle was found to be unnecessary for the exhibition of the two-stage deliquescence transitions during the humidifying process at all mixing ratios. The efflorescence phase diagram (Fig. 4) and the X-ray maps (Fig. 5) showed that effloresced $\mathrm{NaCl}-\mathrm{NaNO}_{3}$ particles of all mixing ratios had $\mathrm{NaCl}$ crystallized homogeneously in the center, surrounded either by the eutonic component for $X_{\mathrm{NaCl}}>0.38$ or $\mathrm{NaNO}_{3}$ for $X_{\mathrm{NaCl}} \leq 0.38$. These micro-structures and spatial distributions of chemical components have obvious atmospheric implications (Ziemann and McMurry, 1997).

\section{Atmospheric implications}

The particle/droplet size variations with $\mathrm{RH}$ for the different mixing states (Fig. 2), the four and three distinct phases observed during the humidifying (Fig. 3) and dehydration (Fig. 4) processes, respectively, have important atmospheric implications in terms of radiative forcing (Baynard et al., 2006; Ma et al., 2008), cloud nucleation efficiency (Petters et al., 2007; Wex et al., 2008), atmospheric chemistry (Ault et al., 2013a; Ryder et al., 2014; Wang and Laskin, 2014), and gas adsorption/desorption (gas-particle partitioning) (Woods et al., 2012). Some of these implications related to the observed experimental results are discussed.

\subsection{Particle size change at different phase transitions}

In this study, the measured $\mathrm{NaCl}-\mathrm{NaNO}_{3}$ mixture particles, $1-10 \mu \mathrm{m}$ in size and their size variations according to the RH change, are atmospherically relevant, because inorganics are dominant in the super-micron or coarse size fraction of SSAs (Keene et al., 2007; Ault et al., 2013b; Prather et al., 2013). In Fig. 6a, 2-D diameter ratios $\left(d / d_{x}=\sqrt{ }\left(A / A_{x}\right)\right.$, where $x$ is the particle state at RHs before the transitions), which represent the size increase due to mutual deliquescence of the eutonic part at MDRH (compared to the rearranged solid particle) as well as to deliquescence of the pure salts at the second DRHs (compared to the partially deliquesced particle at MDRH), were plotted as a function of the $\mathrm{NaCl}$ mole fractions. As shown in Figs. 2 and 6a, the particle size variations during the humidifying process depends on the mixing ratio of the two-component $\mathrm{NaCl}-\mathrm{NaNO}_{3}$ particles as the extent of the increase in particle size due to the 


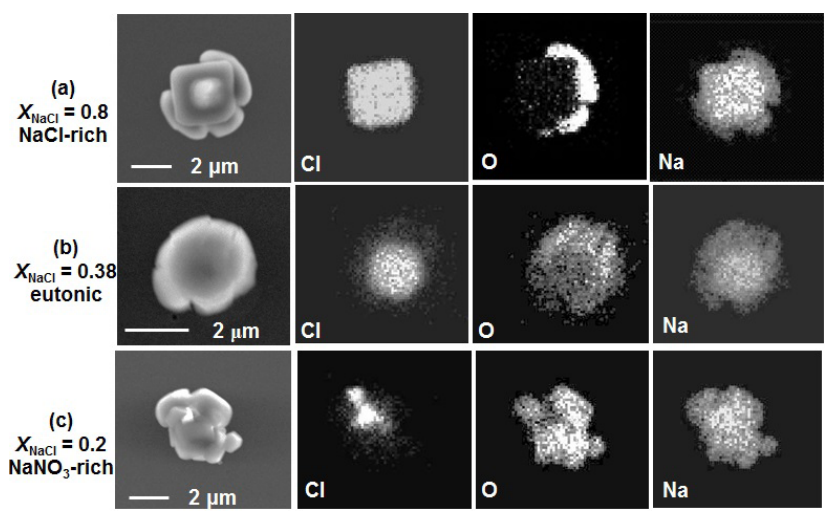

Figure 5. Secondary electron images (SEIs) and elemental $\mathrm{X}$ Ray maps for $\mathrm{Cl}$ (from $\mathrm{NaCl}$ ), $\mathrm{O}$ (from $\mathrm{NaNO}_{3}$ ), and $\mathrm{Na}$ of the effloresced $\mathrm{NaCl}-\mathrm{NaNO}_{3}$ mixture particles with compositions of (a) $X_{\mathrm{NaCl}}=0.8\left(\mathrm{NaCl}\right.$-rich); (b) $X_{\mathrm{NaCl}}=0.38$ (eutonic); and (c) $X_{\mathrm{NaCl}}=0.2\left(\mathrm{NaNO}_{3}\right.$-rich) .

water uptake is associated with the chemical composition of the particles. For single-component $\mathrm{NaCl}$ and $\mathrm{NaNO}_{3}$ particles, their 2-D diameters increase $\sim 2.0$ and $\sim 1.5$ fold, respectively, when they deliquesced at their DRHs (Fig. 6a). The difference was attributed to the different solubility of the salts. Because $\mathrm{NaCl}$ is less soluble than $\mathrm{NaNO}_{3}$ (their solubility is $36.0 / 100 \mathrm{~g}$ and $91.2 / 100 \mathrm{~g}$, respectively) (Lide, 2002), $\mathrm{NaCl}$ requires more water than $\mathrm{NaNO}_{3}$ to form a saturated solution, resulting in a larger increase in size when solid $\mathrm{NaCl}$ particles deliquesce. Therefore, for the mixed $\mathrm{NaCl}-$ $\mathrm{NaNO}_{3}$ particles, the extent of the particle size increases at the MDRH or the second DRH is associated with the mixing ratios of the two salts. At the MDRH, where only the eutonic component deliquesces, the extent of the size increase depends on the fraction of the eutonic component in the particles. Therefore, at the MDRH, particles with a eutonic composition $\left(X_{\mathrm{NaCl}}=0.38\right)$ show the largest increase in size $\left(d / d_{x}=\sim 1.7\right.$ as shown in Fig. 6a). For NaCl-rich particles $\left(X_{\mathrm{NaCl}}>0.38\right)$, the size increase at the MDRH decreases with increasing $\mathrm{NaCl}$ fraction (Figs. $2 \mathrm{~d}-\mathrm{f}$ and $6 \mathrm{a}$ ) because the eutonic fraction, which depends on the $\mathrm{NaNO}_{3}$ content in the particle, decreases with increasing $\mathrm{NaCl}$ mole fraction. In contrast, for $\mathrm{NaNO}_{3}$-rich particles $\left(X_{\mathrm{NaCl}}<0.38\right)$, the size at the MDRH increases with increasing $\mathrm{NaCl}$ fraction (Figs. 2a, $\mathrm{b}$, and 6a), because the eutonic fraction, which depends on the $\mathrm{NaCl}$ content, increases with increasing $\mathrm{NaCl}$ mole fraction. The particle size change at the RHs between MDRH and the second DRH during the humidifying process depends on the residual solid components after the mutual deliquescence. For NaCl-rich particles, the particles with a larger $\mathrm{NaCl}$ fraction grow more at the RHs between MDRH and their second DRHs (Figs. 2d-f and 6a) because the partially deliquesced particles have a larger residual $\mathrm{NaCl}$ solid fraction. In contrast, for the $\mathrm{NaNO}_{3}$-rich particles, the particles with the larger $\mathrm{NaCl}$ fraction grow less (Figs. 2a, b, and 6a), because they have a smaller residual $\mathrm{NaCl}$ solid fraction.

At the first ERH, where efflorescence occurs by the homogeneous nucleation of $\mathrm{NaCl}$, the $\mathrm{NaCl}$-rich and eutonic droplets $\left(X_{\mathrm{NaCl}} \geq 0.38\right)$ show a larger decrease in size for droplets of a larger $\mathrm{NaCl}$ fraction (Fig. 6b). For the $\mathrm{NaNO}_{3}-$ rich droplets, the simultaneous heterogeneous precipitation of the $\mathrm{NaNO}_{3}$ on the homogeneously crystallized $\mathrm{NaCl}$ seeds occurs at their ERH, and the droplets of higher $\mathrm{NaNO}_{3}$ content show a larger decrease in size. The decrease in size at the second efflorescence transition for aerosol particles of $X_{\mathrm{NaCl}} \geq 0.38$ should be governed by the eutonic content in the aerosol particles; i.e., the more eutonic content, the greater the size decrease (Fig. 6b)

Aerosol particles with mixing ratios of $X_{\mathrm{NaCl}} \geq 0.38$ did not show a noticeable change in the 2-D area when the $\mathrm{RH}$ was decreased from their first ERH to the start of the second ERH (MERH) (see Figs. 1g-i and 2c-f). At this RH range, the aerosol particles are expected to gradually decrease in size due to the evaporation of water in the eutonic solution. As discussed above, however, less soluble $\mathrm{NaCl}$ solid particles require more water than $\mathrm{NaNO}_{3}$ to form a saturated solution, resulting in a larger increase in size when $\mathrm{NaCl}$ particles deliquesce (Fig. 6a). On the other hand, when aqueous $\mathrm{NaCl}$ droplets crystallize, more water in the droplets evaporates than when $\mathrm{NaNO}_{3}$ is present in the droplets. For NaClrich droplets, because a large portion of water in the droplet might be removed when $\mathrm{NaCl}$ crystallizes at their first ERH, only a small amount of water remains in the eutonic solution, which evaporates gradually until complete efflorescence occurs, even though shrinkage was not observed well on their optical images. However, in this RH range, the particle boundary appeared to be clearer when it became more concentrated with decreasing RH. Indeed, the change was clear when viewed directly through the optical microscope (unlike the digital images) during the dehydration measurements. The size variations of aerosol particles with different mixing ratios according to the $\mathrm{RH}$ change can help predict their aerodynamic properties and hence their residence time in ambient air. These variations, however, also depend on the original size of the particles, possibly more for sub-micron particles (Hu et al., 2010).

\subsection{Hygroscopic growth and cloud droplet nucleation}

Cloud droplet nucleation can begin when the air is supersaturated with water vapor (i.e., $\mathrm{RH}$ is above $100 \%$ ) and the hygroscopic growth at high RHs are correlated with the cloud condensation nuclei (CCN) activity (Petters et al., 2007; Wex et al., 2008). Under these experimental conditions, the highest working $\mathrm{RH}$ was $\sim 93 \%$. On the other hand, as the DRHs of pure $\mathrm{NaCl}$ and $\mathrm{NaNO}_{3}$ are $75.5( \pm 0.5) \%$ and 74.0 $( \pm 0.5) \%$, respectively, the hygroscopic growth begins at less than $\sim 76 \%$ RH for particles of all mixing ratios. In Fig. 7, the growth factors in terms of the 2-D diameter ratios $\left(d_{95} / d_{0}\right.$ 

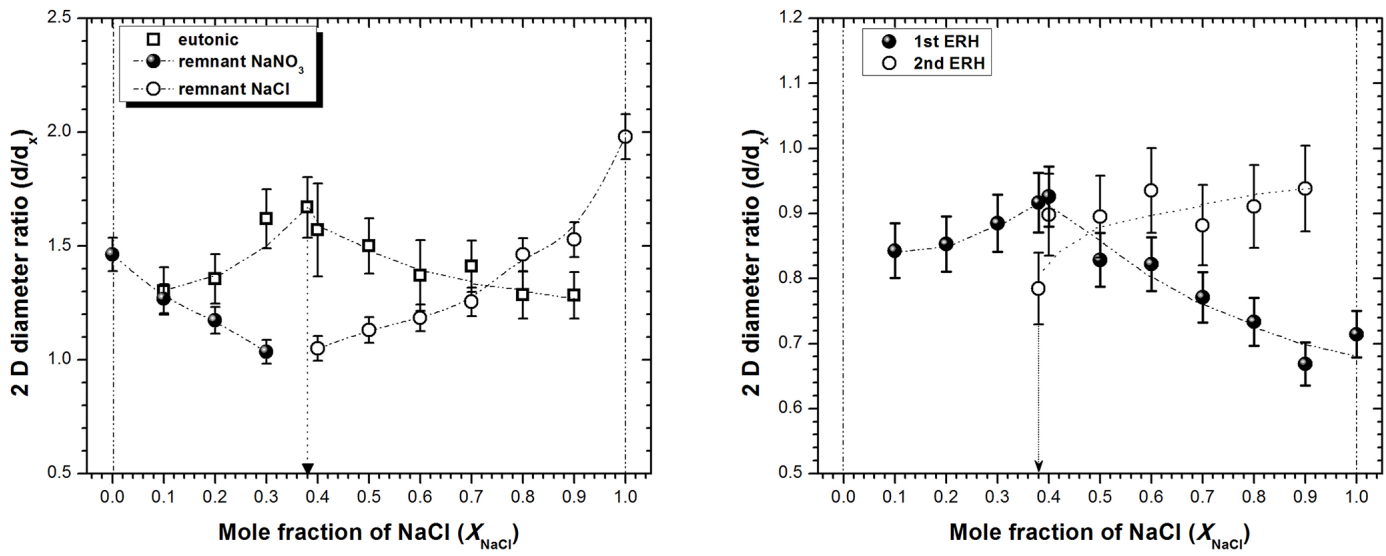

Figure 6. (a) 2-D diameter ratios $\left(d / d_{x}\right)$ of the particles/aerosols plotted as a function of the $\mathrm{NaCl}$ mole fractions $\left(X_{\mathrm{NaCl}}\right)$, which represent the size increase due to the mutual deliquescence of the eutonic part at MDRH (" $d$ ") compared to that of the solid particle at the start of the first transition ( " $d_{x}$ ") (eutonic: open squares); and due to the complete deliquescence of the pure salts (in the figure, $\mathrm{NaNO}_{3}$ : closed circles and $\mathrm{NaCl}$ : open circles) at their second DRHs (" $d$ ") compared to that of the partially deliquesced particle at MDRH (" $d_{x}$ ") and (b) 2-D diameter ratios $\left(d / d_{x}\right)$ of droplets/aerosols plotted as a function of the $\mathrm{NaCl}$ mole fractions $\left(X_{\mathrm{NaCl}}\right)$, which represent the size decrease due to the efflorescence of $\mathrm{NaCl}$ (" $d$ ") compared to that of the liquid droplets at the start of the first efflorescence (" $d_{x}$ ") (first ERH: closed circles); and due to the mutual efflorescence of the eutonic compositions (second ERH: open circles) (" $d$ ") compared to that of the partially effloresced particles ( “ $d_{x}$ ”).

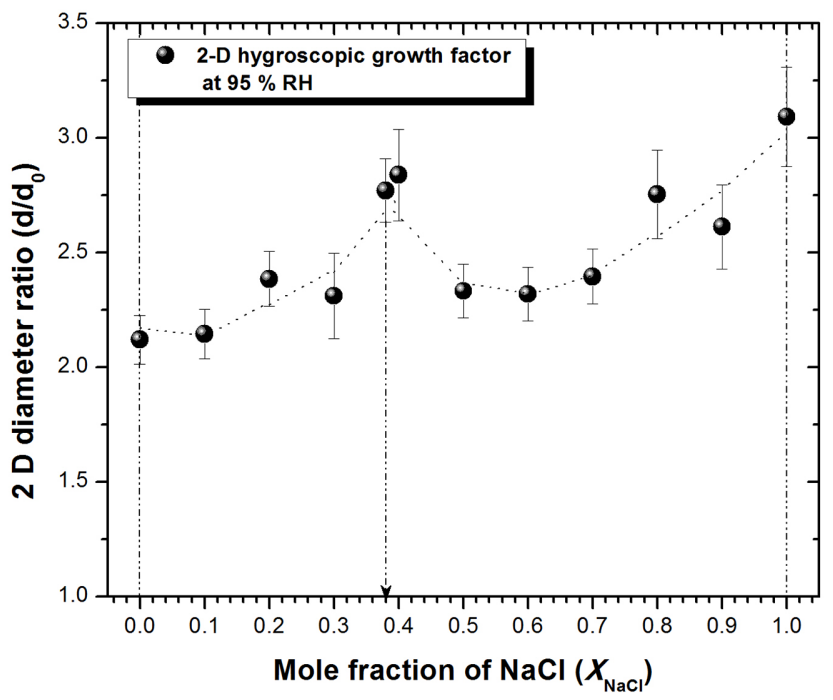

Figure 7. Hygroscopic growth factors in terms of the 2-D diameter ratios $\left(d_{95} / d_{0}\right.$ where $d_{95}=$ the diameter at $\sim 95 \%$, determined by extrapolation, and $d_{0}=$ dry diameter at lowest or $\sim 3 \% \mathrm{RH}$ ) are plotted as a function of the mole fraction of $\mathrm{NaCl}$ for the $\mathrm{NaCl}-$ $\mathrm{NaNO}_{3}$ mixture particles.

where $d_{95}=$ the diameter at $\mathrm{RH}=95 \%$, determined by extrapolation, and $d_{0}=$ dry diameter at $\sim 3 \% \mathrm{RH}$ ) are plotted as a function of the mole fraction of $\mathrm{NaCl}$ for the $\mathrm{NaCl}-$ $\mathrm{NaNO}_{3}$ mixture particles to indicate the cloud droplet nucleation efficiency of these particles at various mixing ratios. $\mathrm{NaCl}$, eutonic, and $\mathrm{NaNO}_{3}$ particles, which have single deliquescence transitions (one DRH), appear to show relatively higher hygroscopic growth (in the following order of $\mathrm{NaCl}>$ eutonic $>\mathrm{NaNO}_{3}$ ) than particles with other mixing ratios, having two-stage deliquescence (MDRH and the second DRH). The hygroscopic growth first decreases with decreasing eutonic content for $\mathrm{NaCl}$-rich particles with $0.38<X_{\mathrm{NaCl}} \leq 0.6$ and then begins to increase with increasing $\mathrm{NaCl}$ content for particles with $0.6<X_{\mathrm{NaCl}} \leq 1.0$. Similar behavior was observed for $\mathrm{NaNO}_{3}$-rich particles. Therefore, for $\mathrm{NaCl}-\mathrm{NaNO}_{3}$ mixture particles, the $\mathrm{CCN}$ efficiency should also follow the same trend. This can serve as a precursor to the hygroscopic growth and CCN activity of more complex, reacted SSAs containing other salts and organics (King et al., 2012). However, an estimation of the full CCN activity and cloud droplet number concentration require further experiments on a wider dry particle size range under both un- and super-saturated conditions (Fuentes et al., 2011; Mochida et al., 2011).

\subsection{Atmospheric chemistry}

The knowledge of mixing states, phases, and spatial distribution of chemicals in $\mathrm{NaCl}-\mathrm{NaNO}_{3}$ mixture particles, as reacted SSA surrogates, at various RHs is expected to help better understand the complexity of real ambient SSAs, their hygroscopic properties, aqueous phase chemistry, etc. For SSAs comprising $\mathrm{NaCl}-\mathrm{NaNO}_{3}$ mixture particles generated from a partial or full reaction with $\mathrm{NO}_{\mathrm{x}} / \mathrm{HNO}_{3}$, their aqueous surface regions are crucial for atmospheric heterogeneous chemistry because the aqueous phases of $\mathrm{NaCl}, \mathrm{NaNO}_{3}$, or the eutonic composed part at different RHs are expected to be available for further reactions with gas phase species, such as $\mathrm{N}_{2} \mathrm{O}_{5}$ (Ault et al., 2013a; Ryder et al., 2014) or organics 
(Wang and Laskin, 2014), and/or for facile gas-particle partitioning (Woods et al., 2012).

SSAs are generated by sea-spray action, so that they are initially aqueous droplets when they become airborne. Although real ambient SSAs are complex mixtures containing $\mathrm{NaCl}$, other inorganic salts, and organics (O'Dowd and de Leeuw, 2007; Keene et al., 2007; Prather et al., 2013; Beardsley et al., 2013; Ault et al., 2013b), $\mathrm{NaCl}$ particles have been studied as genuine SSA surrogates in many laboratories (Martin, 2000; Krieger et al., 2012). Based on the experimental phase diagrams of deliquescence and efflorescence for the $\mathrm{NaCl}-\mathrm{NaNO}_{3}$ system (Figs. 3 and 4), once airborne as droplets, the genuine SSA surrogate would remain in the aqueous phase unless the droplets experience an ambient RH below their ERH of 47.6-46.3\% (pure $\mathrm{NaCl}$ ). Their aqueous phase can facilitate heterogeneous reactions with gaseous species, such as $\mathrm{NO}_{\mathrm{x}} / \mathrm{HNO}_{3}$, to become $\mathrm{NaCl}-$ $\mathrm{NaNO}_{3}$ mixture droplets. When mixture droplets are formed, their full efflorescence occurs at lower RHs (i.e., at MERH of $\sim 33.1 \%$ for the mixture droplets of $X_{\mathrm{NaCl}} \geq 0.38$ or at ERH of $\sim 35-21 \%$ for those of $X_{\mathrm{NaCl}}<0.38$; see Fig. 4) than ERH for pure $\mathrm{NaCl}$, so that their chance for a further gas-particle interaction would be larger with less probability to fully effloresce. Even when the mixed particles become solids due to the full efflorescence below either their MDRH or ERH, they can deliquesce at a lower DRH (i.e., the $\mathrm{NaCl}-\mathrm{NaNO}_{3}$ mixed particles with various mixing ratios partially deliquesce at a MDRH of $\sim 67.9 \%$, whereas pure $\mathrm{NaCl}$ deliquesces at a DRH of $\sim 75.5 \%$; see Fig. 3). In other words, $\mathrm{NaCl}-\mathrm{NaNO}_{3}$ mixture aerosol particles can maintain an aqueous phase over a wider RH range than the genuine SSA surrogate, making their heterogeneous chemistry more probable. Therefore, $\mathrm{NaCl}$-rich particles with higher $\mathrm{Cl}^{-} / \mathrm{NO}_{3}^{-}$can show higher uptake of $\mathrm{N}_{2} \mathrm{O}_{5}$ at ambient RHs (usually $>60 \%$ ) in the marine boundary layer (Ryder et al., 2014). On the other hand, a high uptake of $\mathrm{HNO}_{3}$ due to surface adsorbed moisture on crystalline $\mathrm{NaCl}$ particles has also been reported (Saul et al., 2006; Liu et al., 2007). The ionic activities of aqueous $\mathrm{Na}^{+} / \mathrm{Cl}^{-} / \mathrm{NO}_{3}^{-}$at high to very low water activities during hydration and dehydration, indicating the chemical reactivity of these ions, can be calculated using the AIOMFAC model.

\section{Conclusions}

The hygroscopic behavior and microstructures of mixed $\mathrm{NaCl}-\mathrm{NaNO}_{3}$ particles at various mixing ratios collected on TEM grids were investigated by the use of optical microscopy and SEM/EDX. The DRHs and ERHs of the mixed $\mathrm{NaCl}-\mathrm{NaNO}_{3}$ particles in the micrometer size range at room temperature were determined by monitoring the change in the particle area in 2-D optical images with the RH variation of $\sim 3-93 \%$. During the humidifying process, the particles with a eutonic composition $\left(X_{\mathrm{NaCl}}=0.38\right)$ exhibited singlestage deliquescence behavior at MDRH $=67.9( \pm 0.5) \%$.
The mixed $\mathrm{NaCl}-\mathrm{NaNO}_{3}$ particles, except for the eutonic composition, showed two-stage phase transitions: the first transition at MDRH, which is independent of the chemical compositions, and the second transition at the DRHs, which depends on the mixing ratios of the two salts. For the NaClrich particles $\left(X_{\mathrm{NaCl}}>0.38\right)$, the increase in the mole fraction of $\mathrm{NaCl}$ shifted the DRH toward the pure $\mathrm{NaCl}$ limit (DRH $=75.5 \%)$. For $\mathrm{NaNO}_{3}$-rich particles $\left(X_{\mathrm{NaCl}}<0.38\right)$, the increase in the mole fraction of $\mathrm{NaNO}_{3}$ shifted the DRH toward the pure $\mathrm{NaNO}_{3}$ limit $(\mathrm{DRH}=74.0 \%)$. The measured DRH values agreed well with those calculated from the thermodynamic AIOMFAC model.

The dehydration behavior of the mixed $\mathrm{NaCl}-\mathrm{NaNO}_{3}$ particles depend on the mixing ratios of the two salts. NaCl-rich particles $\left(X_{\mathrm{NaCl}}>0.38\right)$ showed two-stage efflorescence transitions: the first stage, which is driven purely by the homogeneous nucleation of $\mathrm{NaCl}$, and the second stage at MERH. Interestingly, the eutonic composed particles $\left(X_{\mathrm{NaCl}}=0.38\right)$ also showed two-stage efflorescence with $\mathrm{NaCl}$ crystallizing first followed by the heterogeneous nucleation of $\mathrm{NaNO}_{3}$ on $\mathrm{NaCl}$ seeds. $\mathrm{NaNO}_{3}$-rich particles $\left(X_{\mathrm{NaCl}} \leq 0.3\right)$ showed single-stage efflorescence transitions at ERHs progressively lower than MERH due to the slower homogeneous nucleation of $\mathrm{NaCl}$ and the simultaneous heterogeneous efflorescence of $\mathrm{NaNO}_{3}$ on the $\mathrm{NaCl}$ seeds. SEM/EDX elemental mapping shows that effloresced $\mathrm{NaCl}-\mathrm{NaNO}_{3}$ particles of all mixing ratios had $\mathrm{NaCl}$ crystallized homogeneously in the center, surrounded either by the eutonic component for $X_{\mathrm{NaCl}}>0.38$ or $\mathrm{NaNO}_{3}$ for $X_{\mathrm{NaCl}} \leq 0.38$. A pure salt core and eutonic composed solid shell in the dry particle was not necessary for exhibiting the two-stage deliquescence transitions in all mixing ratios.

During humidifying or dehydration processes, the amount of the eutonic composed part drives the particle/droplet growth or shrinkage at the MDRH or MERH (second ERH), respectively, and the amount of pure salts $\left(\mathrm{NaCl}\right.$ or $\mathrm{NaNO}_{3}$ in $\mathrm{NaCl}$ - or $\mathrm{NaNO}_{3}$-rich particles, respectively) does at the second DRHs or first ERHs, respectively. Therefore, their behavior can be a precursor to the optical properties and direct radiative forcing for these atmospherically relevant mixture particles representing the coarse, reacted inorganic SSAs. On the other hand, the hygroscopic growth at a RH of $95 \%$ for the various mixing ratios of these mixture particles can be a precursor to the cloud droplet nucleation efficiency and indirect radiative forcing. In addition, $\mathrm{NaCl}-\mathrm{NaNO}_{3}$ mixture aerosol particles can maintain an aqueous phase over a wider $\mathrm{RH}$ range than the genuine SSA surrogate (i.e., pure $\mathrm{NaCl}$ particles), making their heterogeneous chemistry more likely. 
Acknowledgements. This study was supported by Basic Science Research Program through the National Research Foundation of Korea (NRF) funded by the Ministry of Education, Science and Technology (2012R1A2A1A05026329), by Metrology Research Center funded by the Korea Research Institute of Standards and Science (KRISS - 2013 - 13011055), and by Inha University.

Edited by: M. Ammann

\section{References}

Ahn, K.-H., Kim, S.-M., Jung, H.-J., Lee, M.-J., Eom, H.-J., Maskey, S., and Ro, C.-U.: Combined use of optical and electron microscopic techniques for the measurement of hygroscopic property, chemical composition, and morphology of individual aerosol particles, Anal. Chem., 82, 7999-8009, doi:10.1021/ac101432y, 2010.

Ansari, A. S. and Pandis, S. N.: Prediction of multicomponent inorganic atmospheric aerosol behavior, Atmos. Environ., 33, 745757, doi:1016/S1352-2310(98)00221-0, 1999.

Ault, A. P., Guasco, T. L., Ryder, O. S., Baltrusaitis, J., CuadraRodriguez, L. A., Collins, D. B., Ruppel, M. J., Bertram, T. H., Prather, K. A., and Grassian, V. H.: Inside versus Outside: Ion Redistribution in Nitric Acid Reacted Sea Spray Aerosol Particles as Determined by Single Particle Analysis, J. Am. Chem. Soc., 135, 14528-14531, doi:10.1021/ja407117x, 2013a.

Ault, A. P., Moffet, R. C., Baltrusaitis, J., Collins, D. B., Ruppel, M. J., Cuadra-Rodriguez, L. A., Zhao, D., Guasco, T. L., Ebben, C. J., Geiger, F. M., Bertram, T. H., Prather, K. A., and Grassian, V. H.: Size-Dependent Changes in Sea Spray Aerosol Composition and Properties with Different Seawater Conditions, Environ. Sci. Technol., 47, 5603-5612, doi:10.1021/es400416g, 2013b.

Ault, A. P., Guasco, T. L., Baltrusaitis, J., Ryder, O. S., Trueblood, J. V., Collins, D. B., Ruppel, M. J., Cuadra-Rodriguez, L. A., Prather, K. A., and Grassian, V. H.: Heterogeneous Reactivity of Nitric Acid with Nascent Sea Spray Aerosol: Large Differences Observed between and within Individual Particles, J. Phys. Chem. Lett., 5, 2493-2500, doi:10.1021/jz5008802, 2014.

Baynard, T., Garland, R. M., Ravishankara, A. R., Tolbert, M. A., and Lovejoy, E. R.: Key factors influencing the relative humidity dependence of aerosol light scattering, Geophys. Res. Lett., 33, L06813, doi:10.1029/2005g1024898, 2006.

Beardsley, R., Jang, M., Ori, B., Im, Y., Delcomyn, C. A., and Witherspoon, N.: Role of sea salt aerosols in the formation of aromatic secondary organic aerosol: yields and hygroscopic properties, Environ. Chem., 10, 167-177, doi:10.1071/EN13016, 2013.

Chang, S.-Y. and Lee, C.-T.: Applying GC-TCD to investigate the hygroscopic characteristics of mixed aerosols, Atmos. Environ., 36, 1521-1530, doi:10.1016/S1352-2310(01)00546-5, 2002.

Clegg, S. L., Brimblecombe, P., and Wexler, A. S.: A thermodynamic model of the system $\mathrm{H}^{+}-\mathrm{NH}_{4}^{+}-\mathrm{Na}^{+}-\mathrm{SO}_{4}^{2-}-\mathrm{NO}_{3}^{-}-\mathrm{Cl}^{-}-\mathrm{H}_{2} \mathrm{O}$ at $298.15 \mathrm{~K}$, J. Phys. Chem. A, 102, 2155-2171, doi:10.1021/jp973043j, 1998.

Cohen, M. D., Flagan, R. C., and Seinfeld, J. H.: Studies of concentrated electrolyte solutions using the electrodynamic balance. 2. Water activities for mixed-electrolyte solutions, J. Phys. Chem., 91, 4575-4582, doi:10.1021/j100301a030, 1987a.
Cohen, M. D., Flagan, R. C., and Seinfeld, J. H.: Studies of concentrated electrolyte solutions using the electrodynamic balance. 3. Solute nucleation, J. Phys. Chem., 91, 4583-4590, doi:10.1021/j100301a031, 1987b.

Eom, H.-J., Gupta, D., Li, X., Jung, H.-J., Kim, H., and Ro, C.U.: Influence of Collecting Substrates on the Characterization of Hygroscopic Properties of Inorganic Aerosol Particles, Anal. Chem., 86, 2648-2656, doi:10.1021/ac4042075, 2014.

Finlayson-Pitts, B. J. and Pitts, J. N. J.: Chemistry of the upper and lower atmosphere theory, experiments, and applications, Academic Press, San Diego, 2000.

Freney, E. J., Martin, S. T., and Buseck, P. R.: Deliquescence and Efflorescence of Potassium Salts Relevant to Biomass-Burning Aerosol Particles, Aerosol Sci. Technol., 43, 799-807, 2009.

Freney, E. J., Adachi, K., and Buseck, P. R.: Internally mixed atmospheric aerosol particles: Hygroscopic growth and light scattering, J. Geophys. Res., 115, D19210, doi:10.1029/2009JD013558, 2010.

Fuentes, E., Coe, H., Green, D., and McFiggans, G.: On the impacts of phytoplankton-derived organic matter on the properties of the primary marine aerosol - Part 2: Composition, hygroscopicity and cloud condensation activity, Atmos. Chem. Phys., 11, 25852602, doi:10.5194/acp-11-2585-2011, 2011.

Gao, Y., Yu, L. E., and Chen, S. B.: Efflorescence Relative Humidity of Mixed Sodium Chloride and Sodium Sulfate Particles, J. Phys. Chem. A, 111, 10660-10666, doi:10.1021/jp073186y, 2007.

Gard, E. E., Kleeman, M. J., Gross, D. S., Hughes, L. S., Allen, J. O., Morrical, B. D., Fergenson, D. P., Dienes, T., Galli, M. E., Johnson, R. J., Cass, G. R., and Prather, K. A.: Direct Observation of Heterogeneous Chemistry in the Atmosphere Science, Science, 279, 1184-1187, doi:10.1126/science.279.5354.1184, 1998.

Ge, Z., Wexler, A. S., and Johnston, M. V.: Multicomponent Aerosol Crystallization, J. Colloid Interf. Sci., 183, 68-77, doi:10.1006/jcis.1996.0519, 1996.

Ge, Z., Wexler, A. S., and Johnston, M. V.: Deliquescence Behavior of Multicomponent Aerosols, J. Phys. Chem. A, 102, 173-180, doi:10.1021/jp972396f, 1998.

Gibson, E. R., Hudson, P. K., and Grassian, V. H.: Physicochemical Properties of Nitrate Aerosols: Implications for the Atmosphere, J. Phys. Chem. A, 110, 11785-11799, doi:10.1021/jp063821k, 2006.

Gysel, M., Weingartner, E., and Baltensperger, U.: Hygroscopicity of aerosol particles at low temperatures. 2 . Theoretical and experimental hygroscopic properties of laboratory generated aerosols, Environ. Sci. Technol., 36, 63-68, doi:10.1021/es010055g, 2002.

Haywood, J. and Boucher, O.: Estimates of the direct and indirect radiative forcing due to tropospheric aerosols: A review, Rev. Geophys., 38, 513-543, doi:10.1029/1999rg000078, 2000.

Hoffman, R. C., Laskin, A., and Finlayson-Pitts, B. J.: Sodium nitrate particles: physical and chemical properties during hydration and dehydration, and implications for aged sea salt aerosols, J. Aerosol Sci., 35, 869-887, doi:10.1016/j.jaerosci.2004.02.003, 2004.

Hu, D., Qiao, L., Chen, J., Ye, X., Yang, X., Cheng, T., and Fang, W.: Hygroscopicity of Inorganic Aerosols: Size and Relative Humidity Effects on the Growth Factor, Aerosol Air Qual. Res., 10, 255-264, doi:10.4209/aaqr.2009.12.0076, 2010. 
Keene, W. C., Maring, H., Maben, J. R., Kieber, D. J., Pszenny, A. A. P., Dahl, E. E., Izaguirre, M. A., Davis, A. J., Long, M. S., Zhou, X., Smoydzin, L., and Sander, R.: Chemical and physical characteristics of nascent aerosols produced by bursting bubbles at a model air-sea interface, J. Geophys. Res.-Atmos., 112, D21202, doi:10.1029/2007jd008464, 2007.

Kelly, J. T., Wexler, A. S., Chan, C. K., and Chan, M. N.: Aerosol thermodynamics of potassium salts, double salts, and water content near the eutectic, Atmos. Environ., 42, 3717-3728, doi:10.1016/j.atmosenv.2008.01.001, 2008.

Kim, H.-K., Lee, M.-J., Jung, H.-J., Eom, H.-J., Maskey, S., Ahn, K.-H., and Ro, C.-U.: Hygroscopic behavior of wet dispersed and dry deposited $\mathrm{NaNO}_{3}$ particles, Atmos. Environ., 60, 68-75, doi:10.1016/j.atmosenv.2012.06.011, 2012.

King, S. M., Butcher, A. C., Rosenoern, T., Coz, E., Lieke, K. I., de Leeuw, G., Nilsson, E. D., and Bilde, M.: Investigating Primary Marine Aerosol Properties: CCN Activity of Sea Salt and Mixed Inorganic-Organic Particles, Environ. Sci. Technol., 46, 1040510412, doi:10.1021/es300574u, 2012.

Krieger, U. K., Marcolli, C., and Reid, J. P.: Exploring the complexity of aerosol particle properties and processes using single particle techniques, Chem. Soc. Rev., 41, 6631-6662, doi:10.1039/c2cs35082c, 2012.

Krueger, B. J., Grassian, V. H., Iedema, M. J., Cowin, J. P., and Laskin, A.: Probing Heterogeneous Chemistry of Individual Atmospheric Particles Using Scanning Electron Microscopy and Energy-Dispersive X-ray Analysis, Anal. Chem., 75, 5170-5179, doi:10.1021/ac034455t, 2003.

Laskin, A., Gaspar, D. J., Wang, W., Hunt, S. W., Cowin, J. P., Colson, S. D., and Finlayson-Pitts, B. J.: Reactions at Interfaces As a Source of Sulfate Formation in Sea-Salt Particles, Science, 301, 340-344, doi:10.1126/science.1085374, 2003.

Lee C.-T. and Hsu, W.-C.: The Measurement of Liquid Water Mass Associated with Collected Hygroscopic Particles, J. Aerosol Sci., 31, 189-197, doi:10.1016/S0021-8502(99)00048-8, 2000.

Li, X., Gupta, D., Eom, H.-J., Kim, H., and Ro, C.-U.: Deliquescence and efflorescence behavior of individual $\mathrm{NaCl}$ and $\mathrm{KCl}$ mixture aerosol particles, Atmos. Environ., 82, 36-43, doi:10.1016/j.atmosenv.2013.10.011, 2014.

Lide, D. R. (Ed.): Handbook of Chemistry and Physics Eighty third ed., CRC Press, Boca Raton, Florida, 2002.

Liu, Y., Cain, J. P., Wang, H., and Laskin, A.: Kinetic Study of Heterogeneous Reaction of Deliquesced $\mathrm{NaCl}$ Particles with Gaseous $\mathrm{HNO}_{3}$ Using Particle-on-Substrate Stagnation Flow Reactor Approach, J. Phys. Chem. A, 111, 10026-10043, doi:10.1021/jp072005p, 2007.

Ma, X., von Salzen, K., and Li, J.: Modelling sea salt aerosol and its direct and indirect effects on climate, Atmos. Chem. Phys., 8, 1311-1327, doi:10.5194/acp-8-1311-2008, 2008.

Martin, S. T.: Phase Transitions of Aqueous Atmospheric Particles, Chem. Rev., 100, 3403-3454, doi:10.1021/cr990034t, 2000.

McInnes, L. M., Quinn, P. K., Covert, D. S., and Anderson, T. L.: Gravimetric analysis, ionic composition, and associated water mass of the marine aerosol, Atmos. Environ., 30, 869-884, doi:10.1016/1352-2310(95)00354-1, 1996.

Meskhidze, N., Petters, M. D., Tsigaridis, K., Bates, T., O’Dowd, C., Reid, J., Lewis, E. R., Gantt, B., Anguelova, M. D., Bhave, P. V., Bird, J., Callaghan, A. H., Ceburnis, D., Chang, R., Clarke, A., de Leeuw, G., Deane, G., DeMott, P. J., Elliot, S., Facchini,
M. C., Fairall, C. W., Hawkins, L., Hu, Y., Hudson, J. G., Johnson, M. S., Kaku, K. C., Keene, W. C., Kieber, D. J., Long, M. S., Mårtensson, M., Modini, R. L., Osburn, C. L., Prather, K. A., Pszenny, A., Rinaldi, M., Russell, L. M., Salter, M., Sayer, A. M., Smirnov, A., Suda, S. R., Toth, T. D., Worsnop, D. R., Wozniak, A., and Zorn, S. R.: Production mechanisms, number concentration, size distribution, chemical composition, and optical properties of sea spray aerosols, Atmos. Sci. Lett., 14, 207-213, doi:10.1002/asl2.441, 2013.

Mochida, M., Nishita-Hara, C., Furutani, H., Miyazaki, Y., Jung, J., Kawamura, K., and Uematsu, M.: Hygroscopicity and cloud condensation nucleus activity of marine aerosol particles over the western North Pacific, J. Geophys. Res.-Atmos., 116, D06204, doi:10.1029/2010jd014759, 2011.

O'Dowd, C. D. and de Leeuw, G.: Marine aerosol production: a review of the current knowledge, Philos. T. R. Soc. A, 365, 1753 1774, doi:10.1098/rsta.2007.2043, 2007.

Pandis, S. N., Wexler, A. S., and Seinfeld, J. H.: Dynamics of tropospheric aerosols (Review), J. Phys. Chem., 99, 9646-9659, 1995.

Petters, M. D. and Kreidenweis, S. M.: A single parameter representation of hygroscopic growth and cloud condensation nucleus activity, Atmos. Chem. Phys., 7, 1961-1971, doi:10.5194/acp-71961-2007, 2007.

Prather, K. A., Bertram, T. H., Grassian, V. H., Deane, G. B., Stokes, M. D., DeMott, P. J., Aluwihare, L. I., Palenik, B. P., Azam, F., Seinfeld, J. H., Moffet, R. C., Molina, M. J., Cappa, C. D., Geiger, F. M., Roberts, G. C., Russell, L. M., Ault, A. P., Baltrusaitis, J., Collins, D. B., Corrigan, C. E., Cuadra-Rodriguez, L. A., Ebben, C. J., Forestieri, S. D., Guasco, T. L., Hersey, S. P., Kim, M. J., Lambert, W. F., Modini, R. L., Mui, W., Pedler, B. E., Ruppel, M. J., Ryder, O. S., Schoepp, N. G., Sullivan, R. C., and Zhao, D.: Bringing the ocean into the laboratory to probe the chemical complexity of sea spray aerosol, P. Natl. Acad. Sci., 110, 7550-7555, doi:10.1073/pnas.1300262110, 2013.

Ro, C.-U., Oh, K.-Y., Kim, H., Kim, Y. P., Lee, C. B., Kim, K.H., Osan, J., de Hoog, J., Worobiec, A., and Van Grieken, R.: Single Particle Analysis of Aerosols at Cheju Island, Korea, Using Low-Z Electron Probe X-ray Microanalysis: A Direct Proof of Nitrate Formation from Sea-Salts, Environ. Sci. Technol., 35, 4487-4494, doi:10.1021/es0155231, 2001.

Ryder, O. S., Ault, A. P., Cahill, J. F., Guasco, T. L., Riedel, T. P., Cuadra-Rodriguez, L. A., Gaston, C. J., Fitzgerald, E., Lee, C., Prather, K. A., and Bertram, T. H.: On the Role of Particle Inorganic Mixing State in the Reactive Uptake of $\mathrm{N}_{2} \mathrm{O}_{5}$ to Ambient Aerosol Particles, Environ. Sci. Technol., 48, 1618-1627, doi:10.1021/es4042622, 2014.

Satheesh, S. K. and Moorthy, K. K.: Radiative effects of natural aerosols: A review, Atmos. Environ., 39, 2089-2110, doi:10.1016/j.atmosenv.2004.12.029, 2005.

Saul, T. D., Tolocka, M. P., and Johnston, M. V.: Reactive Uptake of Nitric Acid onto Sodium Chloride Aerosols Across a Wide Range of Relative Humidities, J. Phys. Chem. A, 110, 7614 7620, doi:10.1021/jp060639a, 2006.

Schlenker, J. C. and Martin, S. T.: Crystallization Pathways of Sulfate-Nitrate-Ammonium Aerosol Particles, J. Phys. Chem. A, 109, 9980-9985, 2005.

Seinfeld, J. H. and Pandis, S. N.: Atmospheric chemistry and physics : from air pollution to climate change, 2nd ed., J. Wiley, Hoboken NJ, 1203 pp., 2006. 
Tang, I. N.: Phase Transformation and Growth of Aerosol Particles Composed of Mixed Salts, J. Aerosol Sci., 7, 361-371, doi:10.1016/0021-8502(76)90022-7, 1976.

Tang, I. N. and Munkelwitz, H. R.: Composition and temperature dependence of the deliquescence properties of hygroscopic aerosols, Atmos. Environ., 27A, 467-473, doi:10.1016/09601686(93)90204-C, 1993.

Tang, I. N. and Munkelwitz, H. R.: Aerosol Phase Transformation and Growth in the Atmosphere, J. Appl. Meteorol., 33, 791-796, doi:10.1175/1520-0450(1994)033<0791:APTAGI>2.0.CO;2, 1994a.

Tang, I. N. and Munkelwitz, H. R.: Water activities, densities, and refractive indices of aqueous sulfates and sodium nitrate droplets of atmospheric importance, J. Geophys. Res., 99, 18801-18808, doi:10.1029/94jd01345, 1994b.

Tang, I. N., Munkelwitz, H. R., and Davis, J. G.: Aerosol Growth Studies - IV Phase Transformation of Mixed Salt Aerosols in a Moist Atmosphere, J. Aerosol Sci., 9, 505-511, doi:10.1016/0021-8502(78)90015-0, 1978.

Tang, I. N., Tridico, A. C., and Fung, K. H.: Thermodynamics and optical properties of sea salt aerosols, J. Geophys. Res., 102, 23269-23275, doi:10.1029/97jd01806, 1997.

ten Brink, H. M.: Reactive uptake of $\mathrm{HNO}_{3}$ and $\mathrm{H}_{2} \mathrm{SO}_{4}$ in sea-salt $(\mathrm{NaCl})$ particles, J. Aerosol Sci., 29, 57-64, doi:10.1016/S00218502(97)00460-6, 1998.

Wang, B. and Laskin, A.: Reactions between water-soluble organic acids and nitrates in atmospheric aerosols: Recycling of nitric acid and formation of organic salts, J. Geophys. Res.-Atmos., 119, 2013JD021169, doi:10.1002/2013jd021169, 2014.

Wang, J. and Martin, S. T.: Satellite characterization of urban aerosols: Importance of including hygroscopicity and mixing state in the retrieval algorithms, J. Geophys. Res.-Atmos., 112, D17203, doi:10.1029/2006jd008078, 2007.

Wex, H., Stratmann, F., Hennig, T., Hartmann, S., Niedermeier, D., Nilsson, E., Ocskay, R., Rose, D., Salma, I., and Ziese, M.: Connecting hygroscopic growth at high humidities to cloud activation for different particle types, Environ. Res. Lett., 3, 035004, doi:10.1088/1748-9326/3/3/035004, 2008.
Wexler, A. S. and Clegg, S. L.: Atmospheric aerosol models for systems including the ions $\mathrm{H}^{+}, \mathrm{NH}_{4}^{+}, \mathrm{Na}^{+}, \mathrm{SO}_{4}^{2-}$, $\mathrm{NO}_{3}^{-}, \mathrm{Cl}^{-}, \mathrm{Br}^{-}$, and $\mathrm{H}_{2} \mathrm{O}$, J. Geophys. Res., 107, D14, 4207, doi:10.1029/2001JD000451, 2002.

Wexler, A. S. and Seinfeld, J. H.: Second-generation inorganic aerosol model, Atmos. Environ., 25A, 2731-2748, doi:10.1016/0960-1686(91)90203-J, 1991.

Wise, M. E., Semeniuk, T. A., Bruintjes, R., Martin, S. T., Russell, L. M., and Buseck, P. R.: Hygroscopic behavior of NaClbearing natural aerosol particles using environmental transmission electron microscopy, J. Geophys. Res., 112, D10224, doi:10.1029/2006JD007678, 2007.

Wise, M. E., Freney, E. J., Tyree, C. A., Allen, J. O., Martin S. T., and Russell L. M., and Buseck, P. R.: Hygroscopic behavior and liquid-layer composition of aerosol particles generated from natural and artificial seawater, J. Geophys. Res., 114, D03201, doi:10.1029/2008JD010449, 2009.

Woods, E., Yi, C., Gerson, J. R., and Zaman, R. A.: Uptake of Pyrene by $\mathrm{NaCl}, \mathrm{NaNO}_{3}$, and $\mathrm{MgCl}_{2}$ Aerosol Particles, J. Phys. Chem. A, 116, 4137-4143, doi:10.1021/jp3014145, 2012.

Ziemann, P. J. and McMurry, P. H.: Spatial Distribution of Chemical Components in Aerosol Particles as Determined from Secondary Electron Yield Measurements: Implications for Mechanisms of Multicomponent Aerosol Crystallization, J. Colloid Interf. Sci., 193, 250-258, doi:10.1006/jcis.1997.5075, 1997.

Zuend, A., Marcolli, C., Luo, B. P., and Peter, T.: A thermodynamic model of mixed organic-inorganic aerosols to predict activity coefficients, Atmos. Chem. Phys., 8, 4559-4593, doi:10.5194/acp8-4559-2008, 2008.

Zuend, A., Marcolli, C., Booth, A. M., Lienhard, D. M., Soonsin, V., Krieger, U. K., Topping, D. O., McFiggans, G., Peter, T., and Seinfeld, J. H.: New and extended parameterization of the thermodynamic model AIOMFAC: calculation of activity coefficients for organic-inorganic mixtures containing carboxyl, hydroxyl, carbonyl, ether, ester, alkenyl, alkyl, and aromatic functional groups, Atmos. Chem. Phys., 11, 9155-9206, doi:10.5194/acp11-9155-2011, 2011. 